\title{
New Late Carboniferous Heritschioidinae (Rugosa) from the Kuiu Island area and Brooks Range, Alaska
}

\author{
J. FEDOROWSKI ${ }^{|1|}$ C.H. STEVENS ${ }^{|2|}$ E. KATVALA ${ }^{|3|}$ \\ ${ }^{|1|}$ Institute of Geology, Adam Mickiewicz University \\ Makow Polnych 16, PL-61-606, Poznan, Poland. E-mail: jerzy@amu.edu.pl \\ Department of Geology, San Jose Unversity \\ ${ }^{12}$ ISan Jose, California 95192, USA. E-mail: Calvin.Stevens@sjsu.edu \\ ${ }^{|3|}$ Department of Geology, University of Calgary \\ Calgary, Canada. E-mail: erik.katvala@ucalgary.ca
}

\begin{abstract}
A B S T R A C T
Three new species of the genus Heritschioides, i.e., H. alaskensis sp. nov., H. kuiuensis sp. nov., and $H$. splendidus sp. nov., and Kekuphyllum sandoense gen. et sp. nov. from the northeastern Kuiu Island area and nearby islets, part of Alexander terrane in southeastern Alaska, and Heritschioides separatus sp. nov. from the Brooks Range, Alaska, are described and illustrated. The three new fasciculate colonial coral species from the Kuiu Island area, collected from the Moscovian Saginaw Bay Formation, are phylogenetically related to those of probable Bashkirian age in the Brooks Range in northern Alaska as shown by the presence of morphologically similar species of Heritschioides. These corals from both areas also are related to one species in the Quesnel terrane in western Canada. Kekuphyllum sandoense from the Saginaw Bay Formation of the Kuiu Island area is the only cerioid-aphroid species within the Subfamily Heritschioidinae described so far. The complete early ontogeny of a protocorallite is for the first time described here on a basis of $\mathrm{H}$. kuiuensis sp. nov. and compared to the hystero-ontogeny in order to show similarities and differences in those processes.
\end{abstract}

KEYWORDS $\quad$ Late Carboniferous. Colonial corals. Coral ontogeny. Kuiu Island. Brooks Range.

\section{INTRODUCTION}

This paper is the first of two studies of the middle Late Carboniferous colonial coral faunas of the northeastern Kuiu Island area, part of the Alexander terrane in southern Alaska, and the Brooks Range, northern Alaska (Fig. 1). A more detailed discussion of the Late Carboniferous paleogeography and relationships of various coral faunas will be addressed in that second paper. However, here we note that the Alexander terrane and many other allochthonous terranes accreted to the northern and western margins of Pangaea in the Mesozoic have been interpreted to have been derived from a region between Baltica, Laurentia, and Siberia, in proximity of the northern Caledonides in the Early Paleozoic (Colpron and Nelson, 2011). In the mid Paleozoic time these terranes were dispersed westward and according to Colpron and Nelson (2011) the Alexander and Wrangellia terranes, 
which were hypothesized to have been amalgamated in the Late Carboniferous (Gardner et al., 1988), were somewhat isolated from Laurasia out in the Panthalassa Ocean throughout Late Carboniferous to Early Permian times. During these times the Brooks Range is interpreted to have been in place in northern Alaska (Colpron and Nelson, 2001). In contrast, Katvala and Henderson (2001) placed part of the Wrangellia terrane (Vancouver Island) relatively close to North America, at least in the Early Permian, closer to Pangaea than proposed by Colpron and Nelson (2011). The middle Late Carboniferous colonial corals studied here suggest that the Alexander terrane was located in the general vicinity of the Brooks Range in the Late Carboniferous.

\section{LOCATION AND AGE}

Corals from the Kuiu Island area were collected by A.F. Buddington in 1922 (see Buddington and Chapin, 1929), L.J.P. Muffler in 1965 (see Muffler, 1967), and Erik Katvala in 2004 and 2005. All specimens but one (USGS loc. 27727-PC), which occurs in the "crinoidal limestone" of Muffler (1967), are from the Saginaw Bay Formation (Figs. 1, 2). The specimens collected by Muffler and Buddington were turned over to William Sando of the United States Geological Survey where they were given USGS locality numbers. These specimens were later distributed to Wayne Bamber, Geological Survey of Canada, Calgary, and to Cal Stevens by Sando. Bamber's and Eric Katvala's specimens were delivered to Cal Stevens by Eric Katvala in 2008. Fragments of most specimens were mailed in 2010 to Jerzy Fedorowski, Poznań, Poland for additional studies including making serial sections. The specimen described by Armstrong (1972) from the Brooks Range, Alaska was loaned to Cal Stevens by the Smithsonian Institution, National Museum of Natural History.

Work in progress by Eric Katvala suggests that all of the specimens from the Kuiu Island area described here are Moscovian (Late Carboniferous) in age. The fauna from the Brooks Range was dated by Armstrong (1972) as Atokan (Bashkirian, Late Carboniferous) in age. The coral faunas from these two regions are quite different from all other known coral faunas of middle Late Carboniferous age except for the presence of the somewhat similar type species of Heritschioides in the Quesnel terrane in southern British Columbia.

\section{STRATIGRAPHY}

In the first work on the stratigraphy of the Kuiu Island area, Buddington and Chapin (1929) divided the upper Paleozoic rocks into the "lower division of the Permian" and the "upper division of the Permian". According to Muffler (1967) his newly named Halleck Formation, corresponds to the "lower division" whereas the Pybus Formation of Loney (1964) was considered by Muffler
(1967) to correspond to the "upper division of the Permian" of Buddington and Chapin (1929). Muffler (1967) recognized and named the older Carboniferous rocks in the area: the"crinoidal limestone" and the Saginaw Bay Formation.

Katvala and Henderson (2007) and Katvala et al., (2009) have determined that the local Carboniferous and Permian stratigraphic column consists of the Cannery Formation, an unnamed "crinoidal limestone", the Saginaw Bay Formation, the Halleck Formation, and the Pybus Formation (Fig. 2). The Saginaw Bay Formation was divided by Muffler (1967) into four members. According to him, from older to younger, they were: the Volcanic Member, the Black Chert Member, the Chert and Limestone Member, and the Silty Limestone Member. According to Katvala (personal communication, 2013), however, the Chert and Limestone Member should be included in the Silty Limestone Member, and the Black Chert Member is Devonian in age, based on conodont faunas, and therefore does not belong in the Saginaw Bay Formation. Here the two members of the Saginaw Bay Formation shown on Figure 1 are the Silty Limestone Member, which includes the Chert and Limestone Member of Muffler (1967), and the Volcanic Member.

The corals reported upon here are from the Saginaw Bay Formation. An early Middle Pennsylvanian (Atokan) fauna, probably from the Chert and Limestone Member (sensu Muffler, 1967) of the Saginaw Bay Formation, was first identified by Dutro and Douglass (1961). On the basis of recent conodont studies (Katvala, personal communication, 2013, however, the Saginaw Bay Formation is interpreted to be mostly if not entirely of Moscovian age. This unit is underlain by the "crinoidal limestone" of Bashkirian age (Katvala, personal communication, 2013), and overlain by the Halleck Formation, considered Early Permian in age, based on conodont faunas (Katvala and Henderson, 2007; Fig. 2).

\section{MATERIAL AND METHODS}

Samples from seven localities in the Kuiu Island area, six of which were utilized in this study, were available for study. United States Geological Survey localities are indicated by numbers followed by the letters PC (e.g. USGS 27727-PC). Localities of Eric Katvala are indicated by a combination of letters and numbers. Where several samples of the same species were collected, individual colonies in both collections are indicated by an additional number (e.g. \#1). The geographic position of localities is shown on Figure 1, and detailed descriptions of localities and their stratigraphic positions are indicated in Appendix I. Thin sections of all figured specimens have been assigned the letter $\mathrm{C}$ followed by the number of that slide. Slides of all holotypes are housed in the collections of the National Museum of Natural History and bear a USNM number as well as a $\mathrm{C}$ number. Paratypes, other figured specimens, and other samples collected by Katvala, many containing solitary corals, 

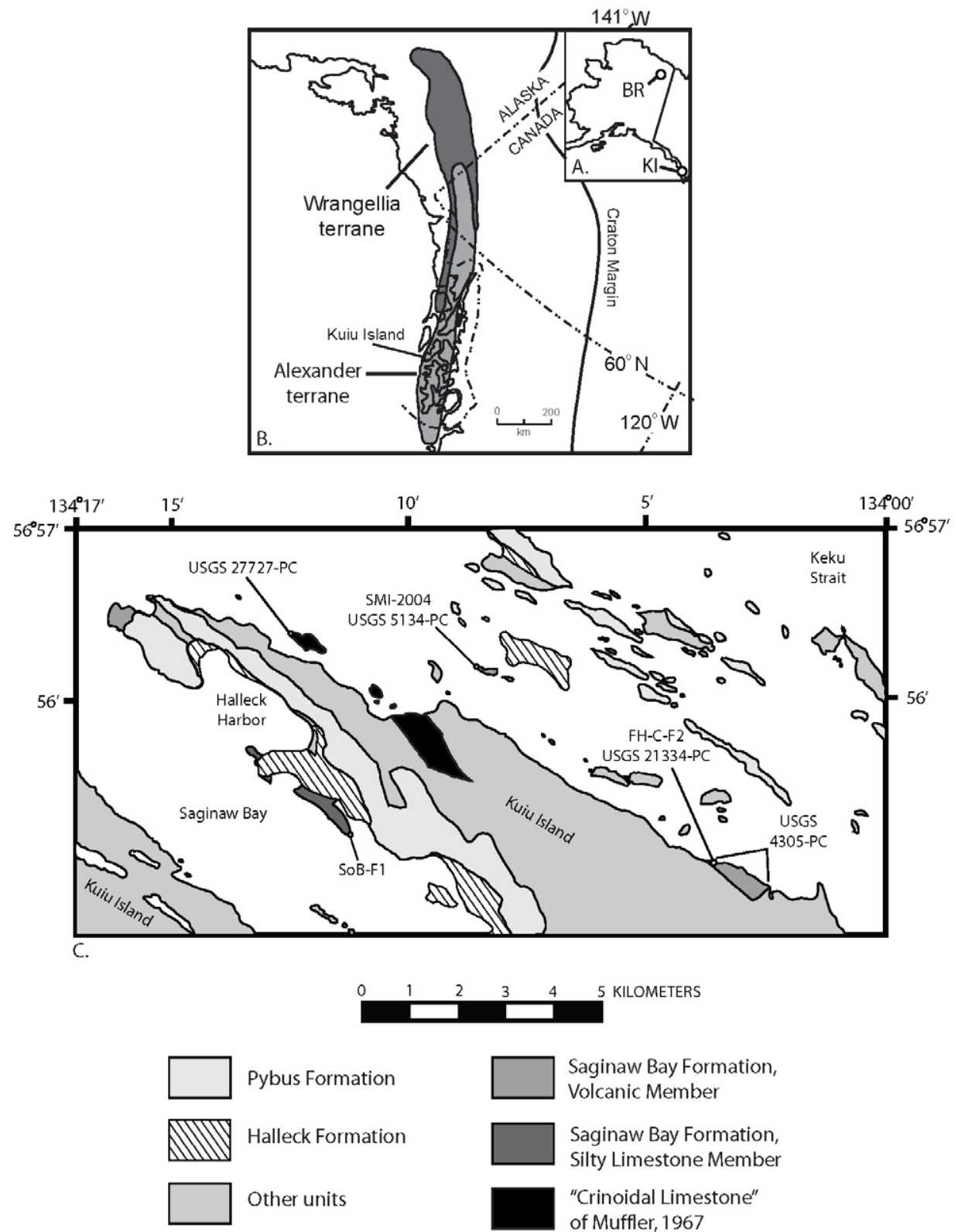

Pybus Formation

Saginaw Bay Formation, Volcanic Member

Halleck Formation

Saginaw Bay Formation, Silty Limestone Member

Other units

"Crinoidal Limestone"

of Muffler, 1967

FIGURE 1 Locations. A) Location of Kuiu Island (KI) and the coral locality in the Brooks Range (BR) in northeastern Alaska. B) Position of Kuiu Island in the Alexander terrane-Wrangellia terrane assembly. C) Location of sampled localities on Kuiu Island and nearby islets plotted on a geologic map of the area.

have been placed in the collections of the University of California Museum of Paleontology at Berkeley.

All specimens have undergone various diagenetic alterations: compression, replacement by dolomite and/or silica, recrystallization, and dissolution resulting in small geode-like structures within skeletons. Those alterations are irregularly distributed within colonies, leaving some corallites or parts of them preserved well enough for photography of the microstructure of septa and for preparation of series of peels elucidating the blastogeny. Some of those series were photographed and drawn using a computer method.
In the description of all species the smallest diameter (d), as seen in transverse section, was measured (in millimeters), and the number ( $\mathrm{n}$ ) of major septa counted. These measurements are recorded as $\mathrm{n}: \mathrm{d}$ values.

\section{SYSTEMATIC PALEONTOLOGY}

Order: Staurida VERRILL, 1865

Suborder: Aulophyllina HILL, 1981

Family: Aulophyllidae DYBOWSKI, 1873 


\begin{tabular}{|c|c|c|}
\hline Period & Age & Formation \\
\hline \multirow[b]{2}{*}{ Perm. } & Middle & Pybus Formation \\
\hline & Early unconformity & Halleck Formation \\
\hline \multirow[t]{2}{*}{ Penn. } & Moscovian & Saginaw Bay Formation \\
\hline & Bashkirian & "crinoidal limestone" \\
\hline Miss. & Serpukhovian & Cannery Formation \\
\hline
\end{tabular}

FIGURE 2 Local Late Paleozoic stratigraphy of the Kuiu Island area.

Subfamily: Heritschioidinae SANDO, 1985

Discussion. Sando (1985) introduced the name Heritschioididae as a new family and included it in the Suborder Lithostrotionina Spassky \& Kachanov, 1971. However, the characteristics of the type genus Heritschioides Yabe, 1950 correspond more closely with those of the Suborder Aulophyllina Hill, 1981 and the Family Aulophyllidae Dybowski, 1873, in which it was placed by Lin et al. (1995), a position accepted by Fedorowski et al. (2007) who restricted clinotabulae to the Praeand Paleo-Tethys taxa, thus informally eliminating that character from the diagnosis of Heritschioides established by Sando (1985, p. 979). Thus, all taxa bearing that important feature are unrelated to the Heritschioidinae and are eliminated from the consideration. Also, the occurrence of two orders of septa - major and minor - considered diagnostic by Sando (1985), are observed in many unrelated taxa and must be eliminated from consideration of subfamily and generic placements.

In this paper we have added a cerioid-aphroid genus to the list of genera included in the subfamily. Thus, the subfamily now consists of Heritschioides Yabe, 1950, Copia Vassilyuk and Kozyreva, 1974 and Kekuphyllum gen. nov.

\section{GENUS Heritschioides YABE, 1950}

Type species: Waagenophyllum columbicum SMITH, 1935

Heritschioides kuiuensis FEDOROWSKI and STEVENS, sp. nov.

Figures 3-7

Etymology. Named for the Island of Kuiu from which the corals were collected

Holotype. USNM 545244 from sample FH-C-F2 \#4.

Locality and age of the holotype. FH-C-F2; Moscovian

Material. Holotype listed above with nine transverse and three oblique longitudinal thin sections, and nineteen peels. Paratype 1, sample FH-C-F2 \#3 with four transverse and six longitudinal thin sections, and 24 peels; paratype 2, sample USGS 21334-PC \#1, with two transverse and one longitudinal thin section; paratype 3, sample USGS 5134-PC with one transverse thin section (not illustrated). Sample USGS 4305-PC \#2 with one transverse and one longitudinal thin section is questionably assigned to this species. See Appendix I for locality information.

Diagnosis. Heritschioides with maximum n:d value 32:16.5, commonly less; complex axial column occupying up to $1 / 2$ corallite diameter, consists of long regular and extra septal lamellae and steeply elevated axial tabellae; median lamella inconspicuous when present; pseudonaotic septa at incipient development; dissepimentarium $1 / 5-1 / 4$ corallite radius; lonsdaleoid dissepiments very rare.

Description. Corallum fasciculate. Corallites closely packed. External wall $0.1-0.2 \mathrm{~mm}$ thick. Corallite diameters generally 6-16mm; n:d = 20:5, 20-22:6, 23:7, 27:11, 28-30:1314. One corallite $32: 23 \times 19 \mathrm{~mm}$ (Fig. $3 \mathrm{~F}$ ) with axial structure either lacking or diagenetically destroyed. Major septa long, moderately thin in dissepimentarium, slightly dilated at margin of tabularium, most lack taper, some penetrate axial column to become confluent with septal lamellae. All those characters similar but variable within and between colonies beginning in late neanic growth stage (compare small corallites in Figs. 3C, G; 7A, B, D, H, I), may be differently accentuated at different growth levels of same corallite. Major septa vary during corallite growth from almost completely confluent through partly isolated to almost completely free from axial structure (e.g. Fig. 7C-A, respectively). Cardinal septum slightly shortened in some largest corallites, hardly distinguishable or elongated towards axial structure in others (Fig. 7A-C). Axial structure may extend into cardinal fossula when cardinal septum slightly shortened (Figs. 4G, right; 7D, right corallite). Minor septa generally short, some extend as prongs into tabularium. Axial column one third to one-half corallite diameter; in transverse view composed of many straight or wavy, very thin septal lamellae including extra lamellae. Length and arrangement of both kinds of septal lamellae highly variable within a single colony; best exemplified by holotype (Fig. 3A-C, G), also present in all paratypes. Up to eight or more rows of steeply dipping axial tabellae and few septal lamellae when longitudinal section well oriented (Fig. 7E, G, J); irregular, shorter, more numerous, and less steeply arranged when section slightly eccentric, i.e. when periphery of axial structure is sectioned (Fig. 7F, upper). Linked axial tabellae at axial column periphery different in shape within same corallite; longer when axial lamellae rare, occasionally interrupted by inner tabellae of tabularium. In transverse section median lamella commonly obscure, thin, absent from parts of mature growth of several corallites, elongated towards and connected to cardinal septum in immature and some mature corallites. Axial structure either absent from some mature corallite growth stages or diagenetically damaged (Fig. 3F). Shallow cardinal fossula marked by slight depression of dissepimentarium in rare corallites, hardly distinguishable in most. Dissepimentarium occupies 1/5-1/4 corallite radius, generally composed of two to four ranks of small, 

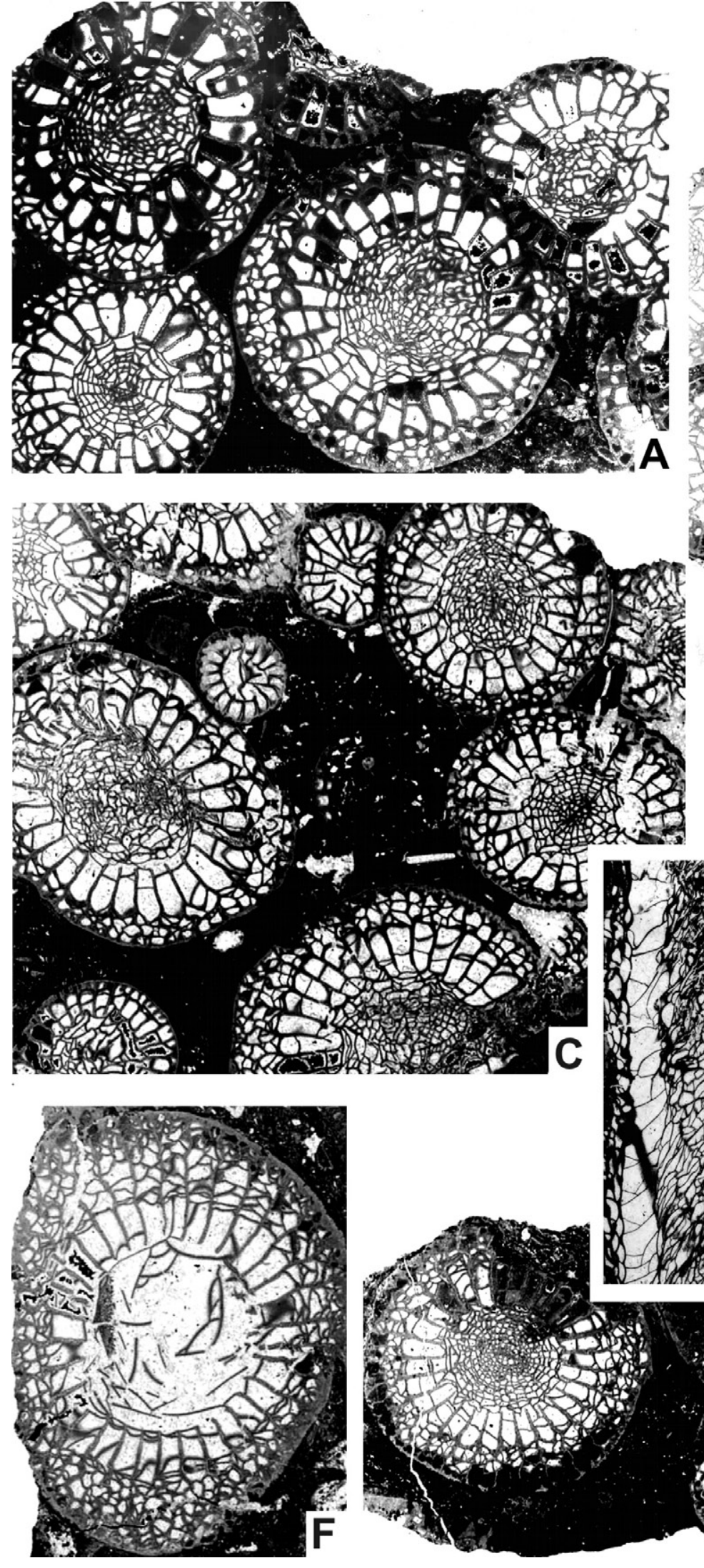
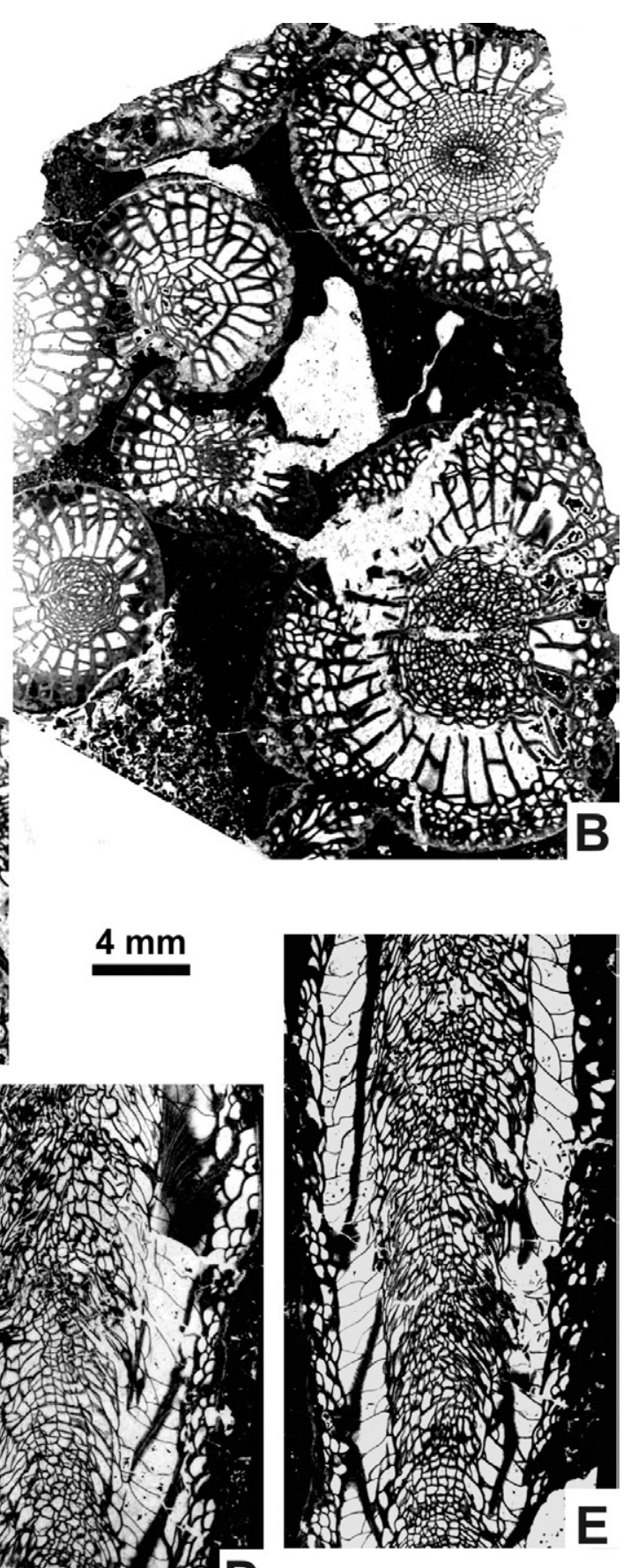

FIGURE 3 $\quad$ Heritschioides kuiuensis sp. nov. Holotype from sample FH-C-F2 \#4. Macromorphology, A-C, F, G) transverse sections; D, E) longitudinal sections. Scale bar applies to all images. 

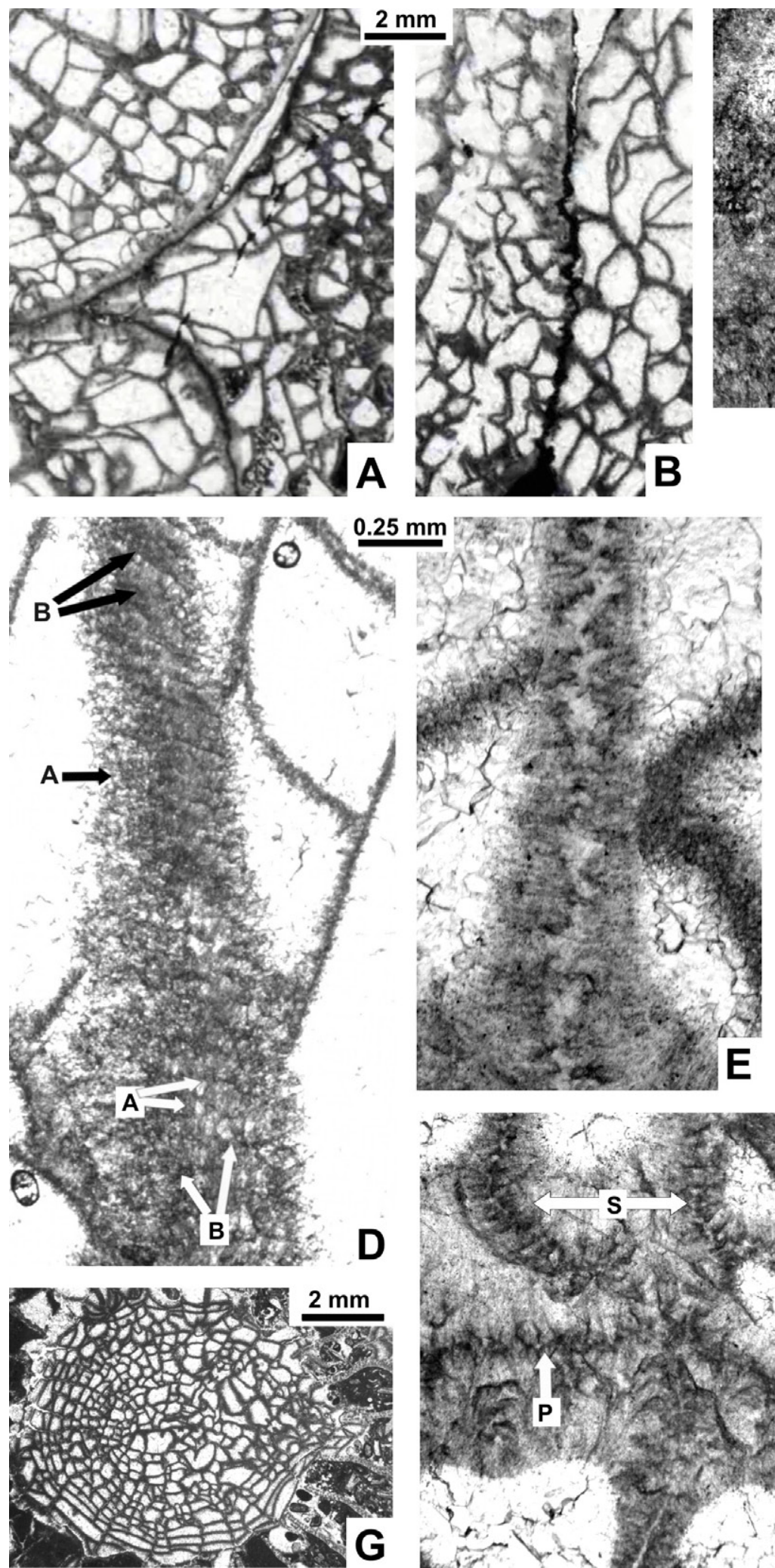
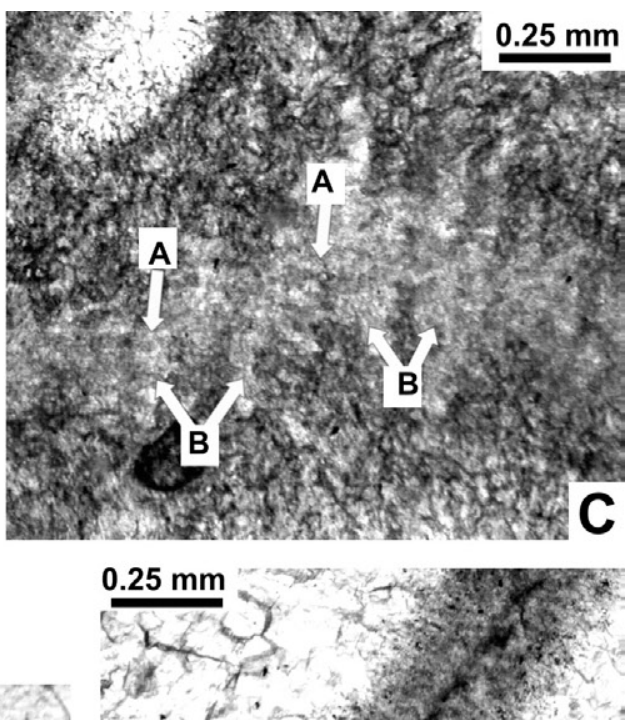
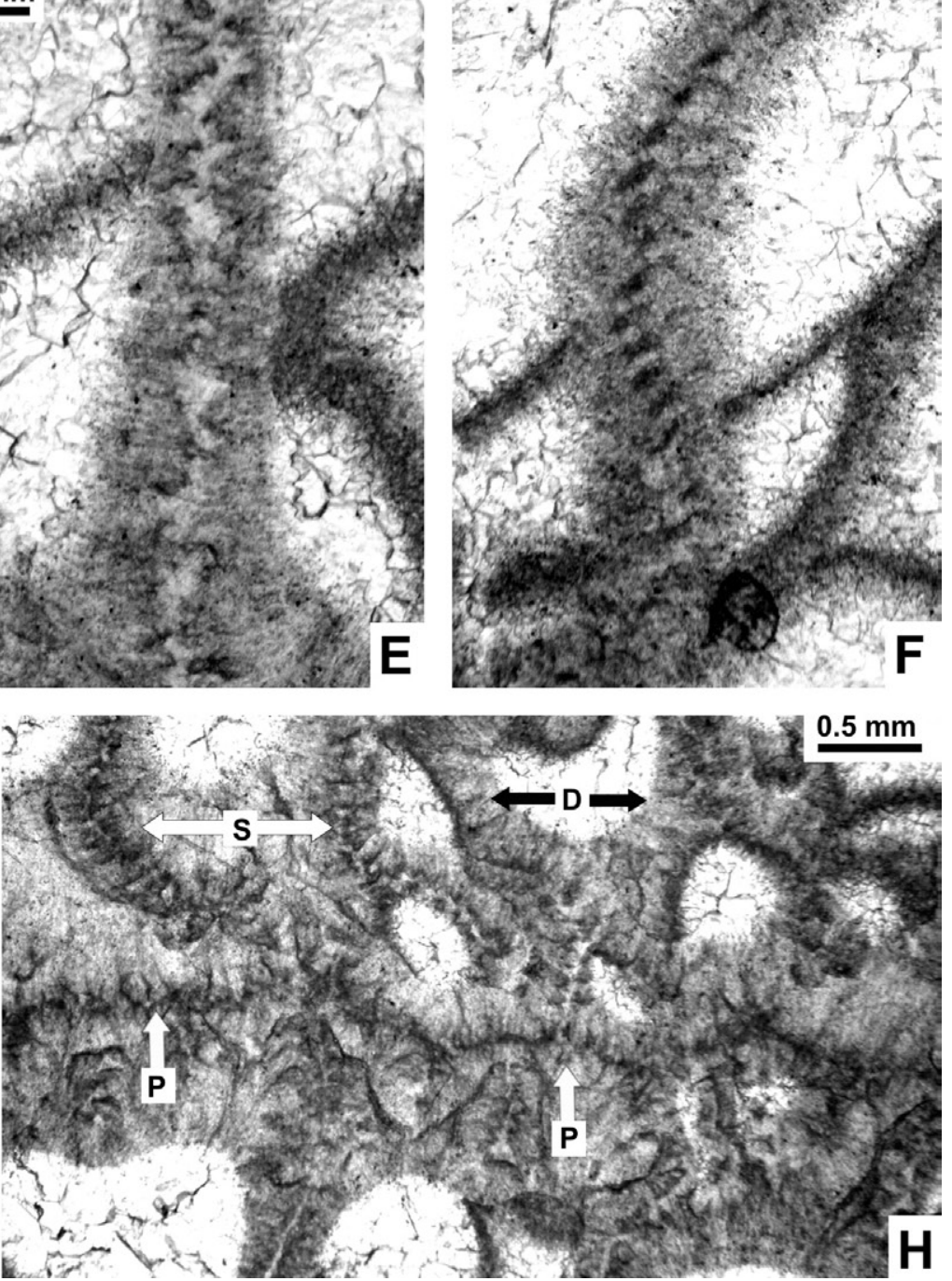

FIGURE 4 Heritschioides kuiuensis sp. nov. Holotype from sample FH-C-F2 \#4 except for D. Details, A, B, E, G, H) transverse sections; A) three densely packed corallites, periphery of right corallite fills space between other two; B) contact between two corallites diagenetically the result of compaction; C, D) remnants of trabeculae (arrows with A) and growth lines (arrows with B) in strongly oblique sections; D) paratype 1 from sample FH-C-F2 \#3; E) well oriented transverse section of septum; trabeculae destroyed by recrystallization; F) growth lines of primary septum (dark) in oblique and relatively well oriented longitudinal section; G) axial structure extending into cardinal fossula (right); H) partition (arrows with P) between parent and offset corallites, septa (arrows with S) and earliest dissepiments (arrows with D). 
mostly globose dissepiments as seen in longitudinal section (Fig. 3D, E; 7E, F, G, J). In transverse sections interseptal, irregular dissepiments located mainly in middle part of dissepimentarium, few lonsdaleoid. Small dissepiments, oblique to larger ones and to septa, grouped mostly at periphery of largest specimens, constitute first step in formation of pseudonaotic septa. Tabularium with incipient biformity in rare septal loculi, composed of complete and incomplete tabulae rather steeply inclined upward to axial column, eight $-10 / \mathrm{mm}$. Boundary of tabularium with dissepimentarium marked by light stereozone thickening.

Microstructure diagenetically altered in most septa (Fig. 4E, F). Remnants of fine trabeculae apparent in oblique sections of reasonably well preserved septa in holotype and one paratype (Fig. $4 \mathrm{C}$, D, respectively), $30 \mu \mathrm{m}$ wide, and separated from one another by similar distances; diagenetic alterations may have increased trabeculae thickness. Shape and width of "dark middle lines" (= the primary septa) depends on orientation of thin sections; in well oriented transverse sections (Fig. 4E) fans of crystalline fibrils of various sizes form an axial sector of septum irregular in shape and width, probably result of significant diagenetic alteration of trabeculae; similar appearing "middle dark lines" in septa in other specimens in all three species of Heritschioides described in this paper also probably represent fine trabecular microstructure. Longitudinal sections exhibit growth bands within septa, shape of which depends on orientation of septum relative to cut surface; bands appear more distinctive when cut oriented obliquely to septal axis and tend to unite when cut perpendicular to axis (Fig. 4F, lower and upper, respectively).

External walls of corallites when in direct contact (Fig. 4A, left side) may appear as a partition, but its two partite character obvious where corallites separate (Fig. 4A, B, upper). Due to dissolution corallites may be crowded, contacts between adjacent corallite walls may become stylolitic (Fig. 4B, most), or parts of adjacent corallites may be destroyed (Fig. 3B, G; Fig. 7C).

Partitions present between an offsetting individual and its bud (Fig. 4H, arrow with 'P') documents a direct connection of the parent and the offset polyp. It closely resembles microstructure of septa (Fig. 4H, arrow with ' $\mathrm{S}$ ') in showing diverging bunches of microcrystalline fibrils, suggesting its secretion in a narrow endodermal fold, closely comparable to a septal pocket. That microstructure differs from dividing walls, dissepiments (Fig. $4 \mathrm{H}$, arrow with ' $\mathrm{D}$ ') and tabulae, in which microcrystalline fibrils grow only in one direction (as has previously been documented independently by Wells (1969) and Sorauf (1970). Partition microstructure similar to that of septa suggesting trabecular origin.

Blastogeny investigated in short series of transverse sections of three neighboring holotype offsets (Fig. 5A-C). Two marked 'a', 'b' derived from upper left parent's corallite; offset 'c' derived from upper right parent's corallite. Information from immature corallites in random transverse sections also employed. Hystero-
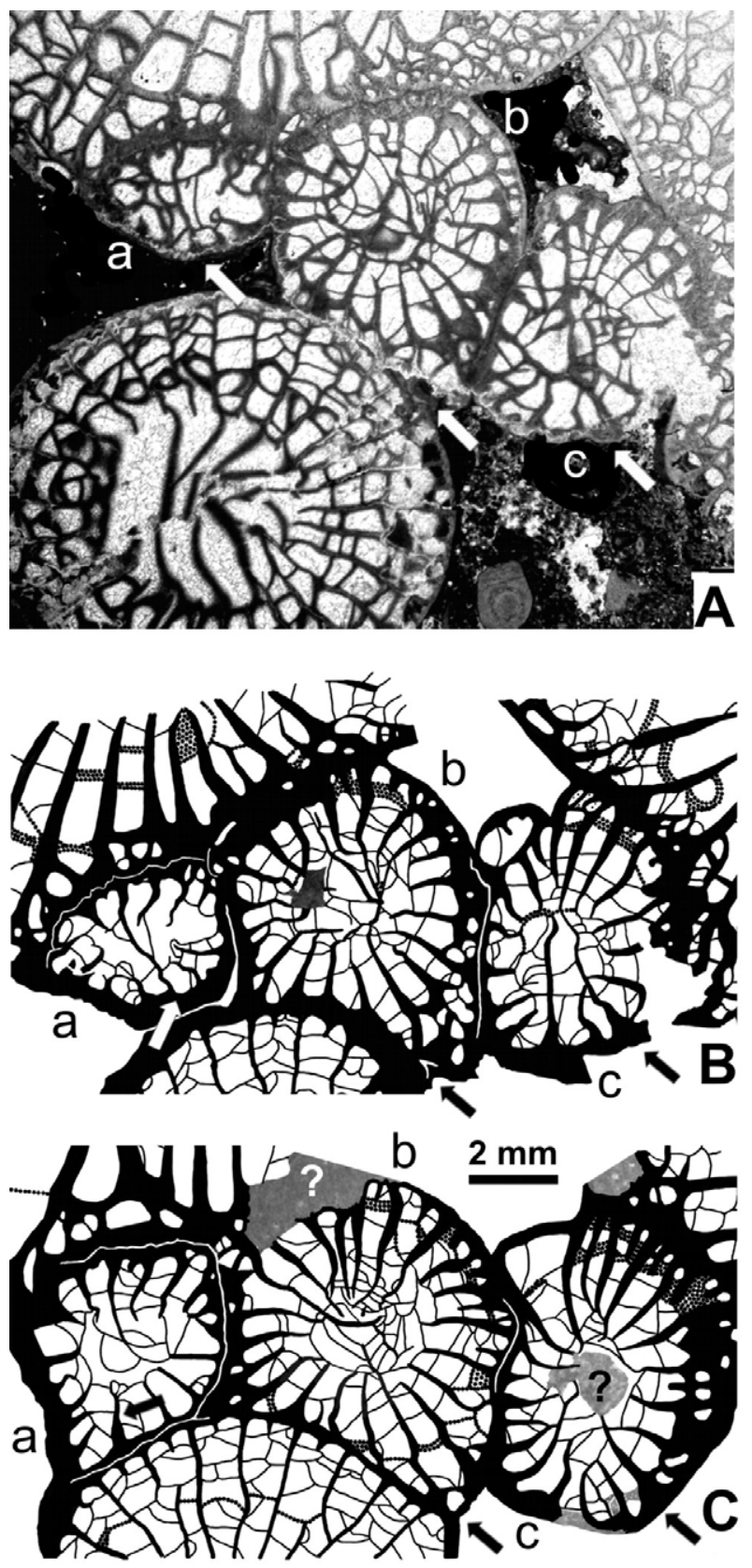

FIGURE 5 1 Heritschioides kuiuensis sp. nov. Holotype from sample $\mathrm{FH}-\mathrm{C}-\mathrm{F} 2$ \#4, A) transverse thin section and B, C) drawings based on peels; variability in early blastogeny of three adjacent offsets. Diagenetically destroyed areas left gray with "?" when important. Cardinal septa marked by black and /or white arrows. Scale bar applies to all images.

brephic growth stage unknown. In early hystero-neanic growth stage (Fig. 5A, B, corallite 'a') axial septum intersects offset's lumen; other septa, exclusively major, short and wavy. Cardinal septum, probably an atavoseptum, located at offset's periphery, withdrawn from corallite axis at slightly more advanced growth stage, not shorter than other major septa. Counter septum remains long (Fig. 5C, corallite ' $a$ '). Withdrawal of cardinal septum from corallite axis variable. In offset ' $b$ ' level at which cardinal septum 
withdrew unknown; that septum increases in length during growth (Fig. 5A-C, corallite 'b'), becoming dominant, as typical in more advanced growth stages. In offset 'c' (Fig. 5A, B) dissepiments already developed; cardinal septum extends beyond corallite axis and meets counter septum, remains longest septum in cardinal quadrants during further growth (Fig. 5C, corallite 'c'), exact length camouflaged by diagenetic alteration in offset's axial area. Formation of median lamella from protosepta not observed; septal lamellae of some other major septa developed in most advanced offset (Fig. 5C, offset 'b'). Transverse sections of some paratype offsets (Fig. 7A, B, D, H, I) illustrate more advanced steps in offset's development. Corallite diameters increase a little; their dissepimentaria and minor septa already developed; axial structures well developed, and may become partly isolated from inner margins of major septa. Median lamella unrecognizable or weak; when recognizable connected to cardinal septum. Underdevelopment of median lamella, characteristic of mature corallites, starts in early hystero-ontogeny, typical for this species. Septal lamellae weakly developed at this stage; regular and extra septal lamellae strongly developed in mature growth stage.

Early ontogeny of one protocorallite attached to a mature
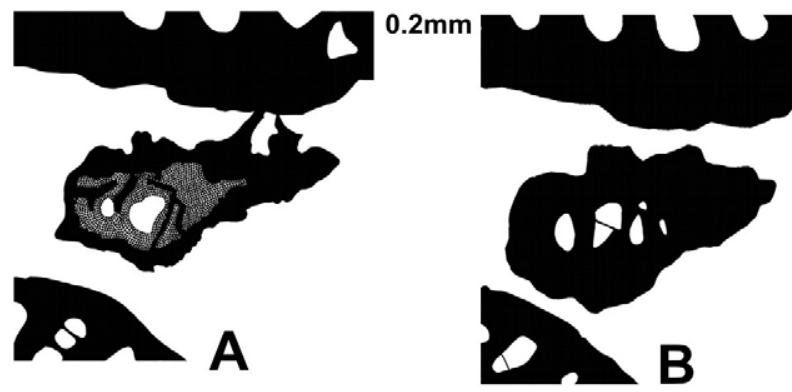

$1 \mathrm{~mm}$

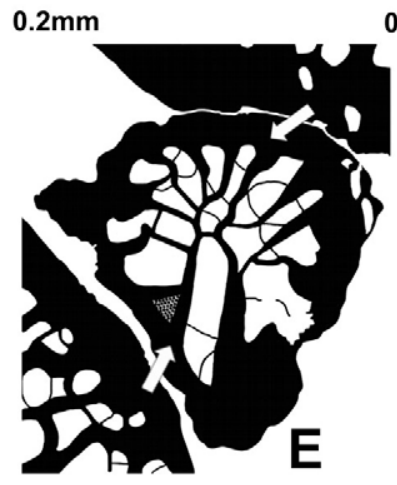

$0.2 \mathrm{~mm}$

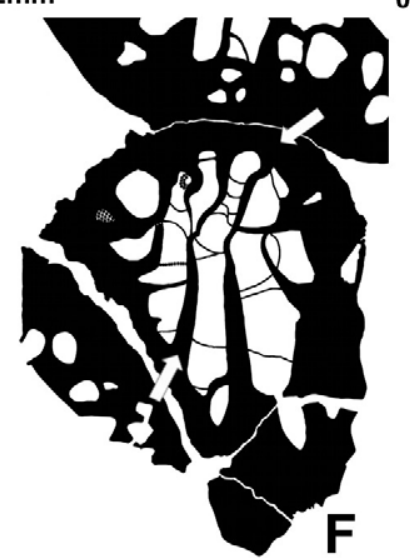

$0.2 \mathrm{~mm}$
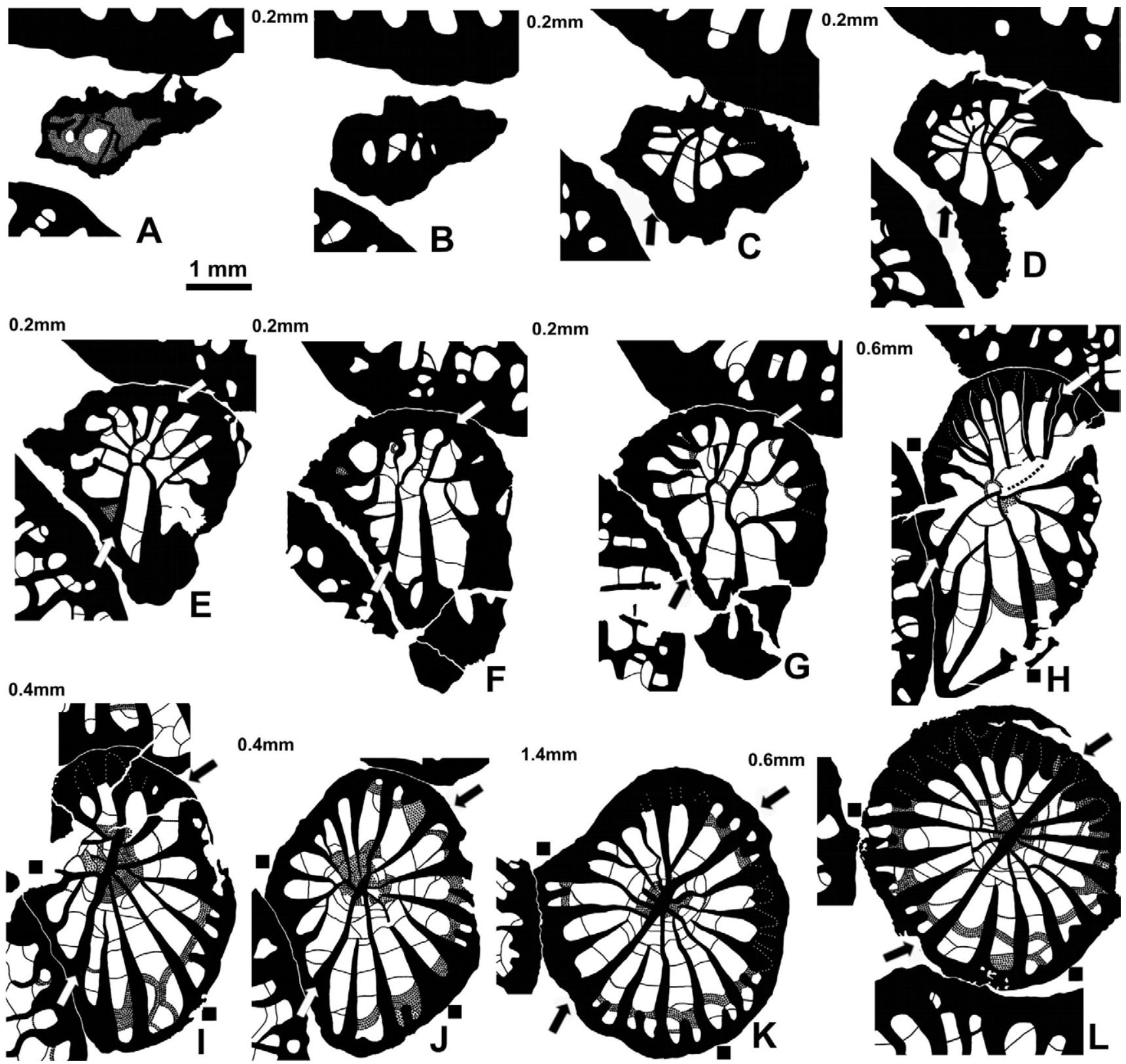

FIGURE 6 $\quad$ Heritschioides kuiuensis sp. nov. Paratype 1 from sample FH-C-F2 \#3. Transverse sections. Early ontogeny of protocorallite developed inside colony. A, B) brephic growth stage; C-H) neanic growth stage; I-L) late neanic/early mature growth stage. Cardinal and counter septa marked by black and/or white arrows. Alar septa where recognizable marked by black quadrangles. Scale bar applies to all images. 

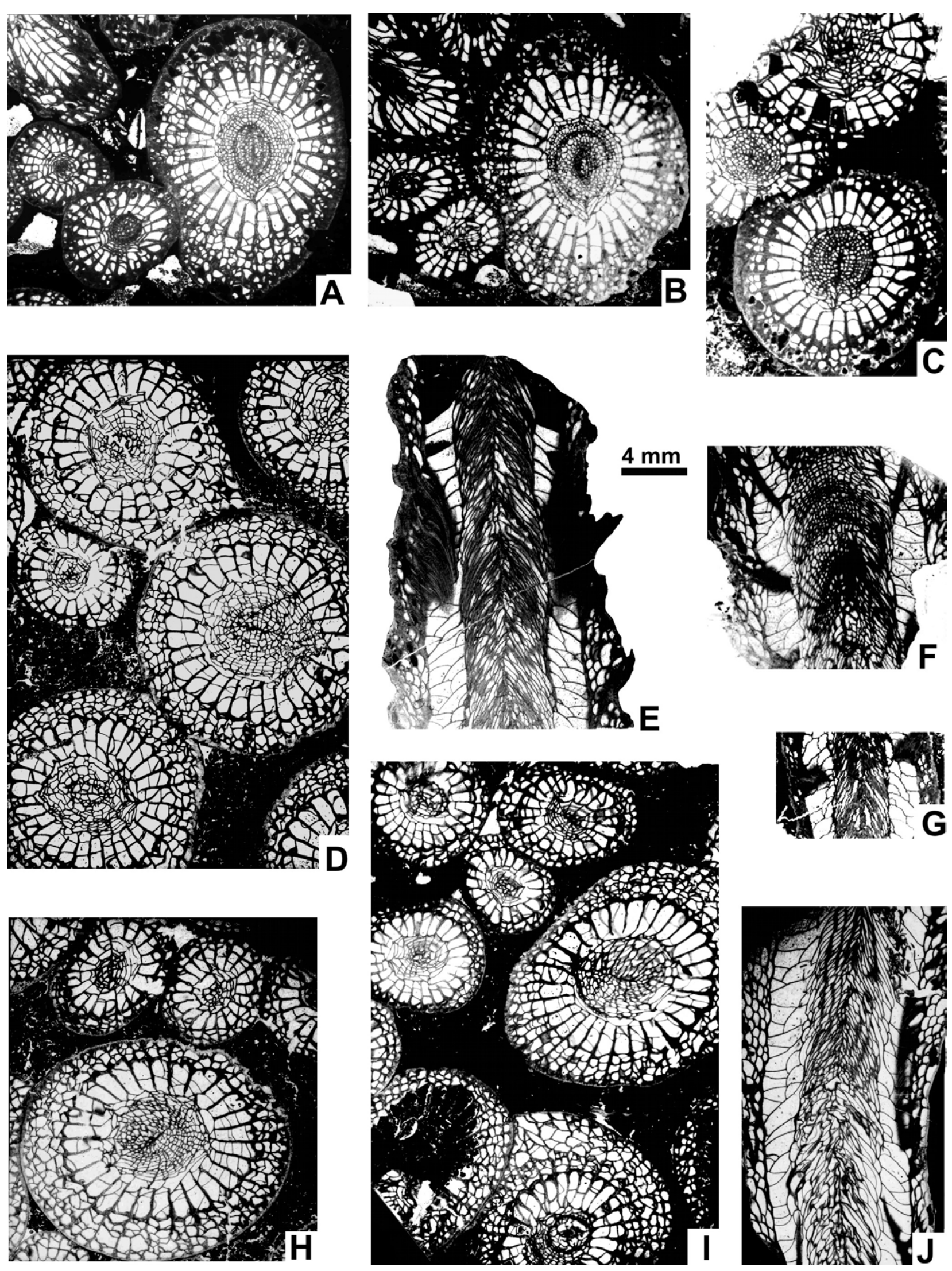

FIGURE 7 Heritschioides kuiuensis sp. nov. Paratypes. Paratype 1 from sample FH-C-F2 \#3, A-C) transverse sections; E-G) longitudinal sections. Paratype 2 from sample 21334-PC \#1, D, H, I) transverse sections; J) longitudinal section. Scale bar applies to all images. 
clone inside paratype 1 (Fig. 6) has allowed the first complete study of this kind published. Diagenetic alterations destroyed some details, including earliest ontogeny; most important characteristics of protocorallite preserved. First two drawings (Fig. 6A, B) correspond to curved part of specimen. Obliqueness and dolomitization precludes deciphering increase and arrangement of septa in brephic growth stage. In ontogenetically earlier stages (Fig. 6A), only vague outlines of probable septa recognizable within sclerenchymal mass; three bodies, septal in microstructure, intersect corallite lumen $0.2 \mathrm{~mm}$ higher (Fig. 6B). Left body may correspond to cardinal septum (Fig. 6C, marked by an arrow), which with major septum in middle dominate in next 0.8 millimeters of growth (Fig. 6D-G). Increased number and arrangement of septa irregular. Protosepta do not dominate in early ontogeny (Fig. 6 D-G); become obvious only after axial septum clearly constituted (Fig. 6I). Length and attachment of other major septa to one another also changes, commonly quickly, during neanic corallite growth (Fig. 6D-H); reason for irregularity unknown, corresponds to that observed in blastogeny (see above). Arrangement of major septa becomes more regular after axial septum formed (Fig. 6I-L); still number of septa in various quadrants uncertain. Recognizable alar septa marked by black quadrangle (Fig. 6H-L).

Late neanic growth stage of specimen arbitrarily placed at insertion of first dissepiments and appearance of minor septa in corallite lumen, both appearing in right cardinal and right counter quadrant first (Fig. 6H, I). Axial structure formed at approximately same level, consists of axial part of axial septum, inner margins of major septa attached to it, and several sections of axial tabellae; remains united with inner margins of major septa for at least $1.2 \mathrm{~mm}$ of growth (Fig. 6I-L). All axial skeletal elements, including axial tabellae, strongly thickened by sclerenchyme; this and diagenetic alterations make axial structure - perhaps an axial column - appear solid. Individual skeletal elements scarcely recognizable in peels; some small details in drawings subjective interpretations of senior author.

In early ontogeny and hystero-ontogeny (blastogeny) protosepta connected and in variable positions; major septa variously elongated. In contrast to hystero-ontogeny, major septa, including protosepta not shortened during early ontogeny, and both protosepta equally strong when axial structure begin to develop; strong and regular in young protocorallite, weak and irregular in offsets. Absence in literature of any detailed studies of ontogeny and blastogeny of any other species of Rugosa, excludes possibility of making comparisons.

Discussion. H. kuiuensis differs from the type species of the genus, H. columbicum (Smith, 1935), from the late Serpukhovian to early Bashkirian from Keremeos in southern British Columbia, Canada, in possessing a much wider and more complex axial column composed of long regular and extra septal lamellae, in having a much narrower and simpler dissepimentarium with very few lonsdaleoid dissepiments, and showing the beginning of pseudonaotic septa. H. kuiuensis differs from the Atokan species, H. separatus sp. nov., from the eastern Brooks Range, Alaska, in the development of a much more complex axial column clearly isolated from the tabularium and consisting of numerous regular and extra septal lamellae, and in a narrower, simpler dissepimentarium. That colony was described and figured by Armstrong (1972, pl. 4, fig. 3 and pl. 5, figs. 3, 4) as a paratype of his new species Corwenia jagoensis.

Occurrence. Locality FH-C-F2; USGS 21334-PC; USGS 5134PC; ?USGS3405-PC.

Heritschioides splendidus FEDOROWSKI and STEVENS, sp. nov.

Figures 8, 9

Etymology. Lat. splendidus-impressive. After large size and elegant morphology of corallites.

Holotype. USNM 545245 from sample SOB F1.

Locality and age of the holotype. One corallum from locality SOB F1, Kuiu Island, Alaska; Moscovian in age.

Material. Holotype listed above with 10 transverse and five longitudinal thin sections, and fourteen peels. See Appendix I for locality information.

Diagnosis. Heritschioides with n:d values up to 41:29x25mm, major septa considerably dilated in tabularium, some minor septa enter tabularium; tabular cardinal fossula present; axial structure $1 / 3$ corallite diameter; median lamella commonly reduced; dissepimentarium 1/5-1/3 corallite radius; lonsdaleoid dissepiments absent.

Description. Corallum fasciculate; fragment available for study originally greater than $18 \mathrm{~cm}$ diameter. Corallites seldom offsetting. Offsets appear at similar levels of astogeny (Fig. 8D). Dimensions measured at different growth levels of corallite ' $a$ ': $36: 21.5 \times 23.5 \mathrm{~mm}$ and $38: 24.5 \times 25.5 \mathrm{~mm}$ after $3 \mathrm{~cm}$ growth; of corallite 'b': 40:26.5 x 30.5mm, 41:24.0 x 28.5mm and 41:24.8 x $29.0 \mathrm{~mm}$ after $5.5 \mathrm{~cm}$ and $3 \mathrm{~cm}$ growth, respectively (Fig. $8 \mathrm{~A}-$ D). External wall 0.06-0.1 mm thick. Major septa long, inner margins of most separated from axial column, few confluent with septal lamellae, thin in dissepimentarium, highly dilated in tabularium, tapering very slightly if at all toward axial column when free-ended, rapidly and strongly tapering when extending towards axial column (Fig. 8A-G). Cardinal septum in mature specimens slightly shortened, located in inconspicuous, parallelwalled cardinal fossula. Minor septa most often extend through dissepimentarium, rarely penetrate into tabularium as prongs. Axial column continuous, one-forth to one-third corallite diameter, composed of many septal lamellae, including extra lamellae and numerous, densely packed axial tabellae. Two arrangements of septal lamellae shown by transverse sections of two adjacent mature corallites: centripetal with densely packed septal lamellae at periphery with few approaching and/or reaching corallite axis (Fig. 8A, D, G, corallite 'a'; Fig. 9A), and irregularly twisted 


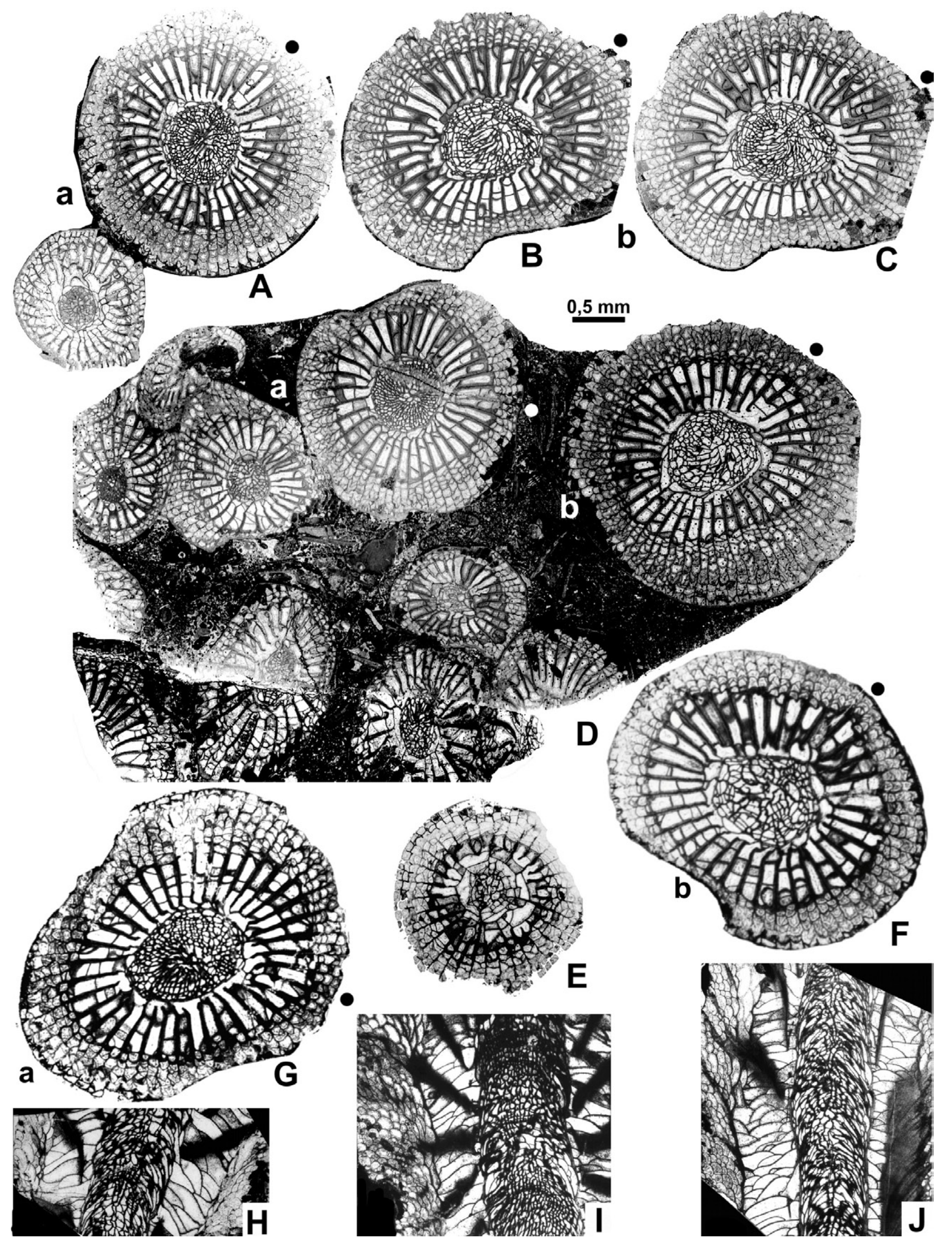

FIGURE 8 Heritschioides splendidus sp. nov. Holotype from sample SOB-F1. Macromorphology, A-G) transverse sections. Morphological changes in sequential sections of mature corallites 'a' and 'b', H-J) longitudinal sections. Cardinal septa marked by black and/or white dots. Scale bar applies to all images. 
(Fig. 8B-D, F, corallite 'b'). In mature corallites median lamella indistinguishable irrespective of arrangement of septal lamellae. Eccentric longitudinal sections cut at dense, peripheral part of axial column (Fig. 8I) show septal lamellae closely crowded, in more centric sections (Fig. 8H, J) fewer septal lamellae exposed. Axial tabellae hemispherical with lateral tabellae well developed, clearly
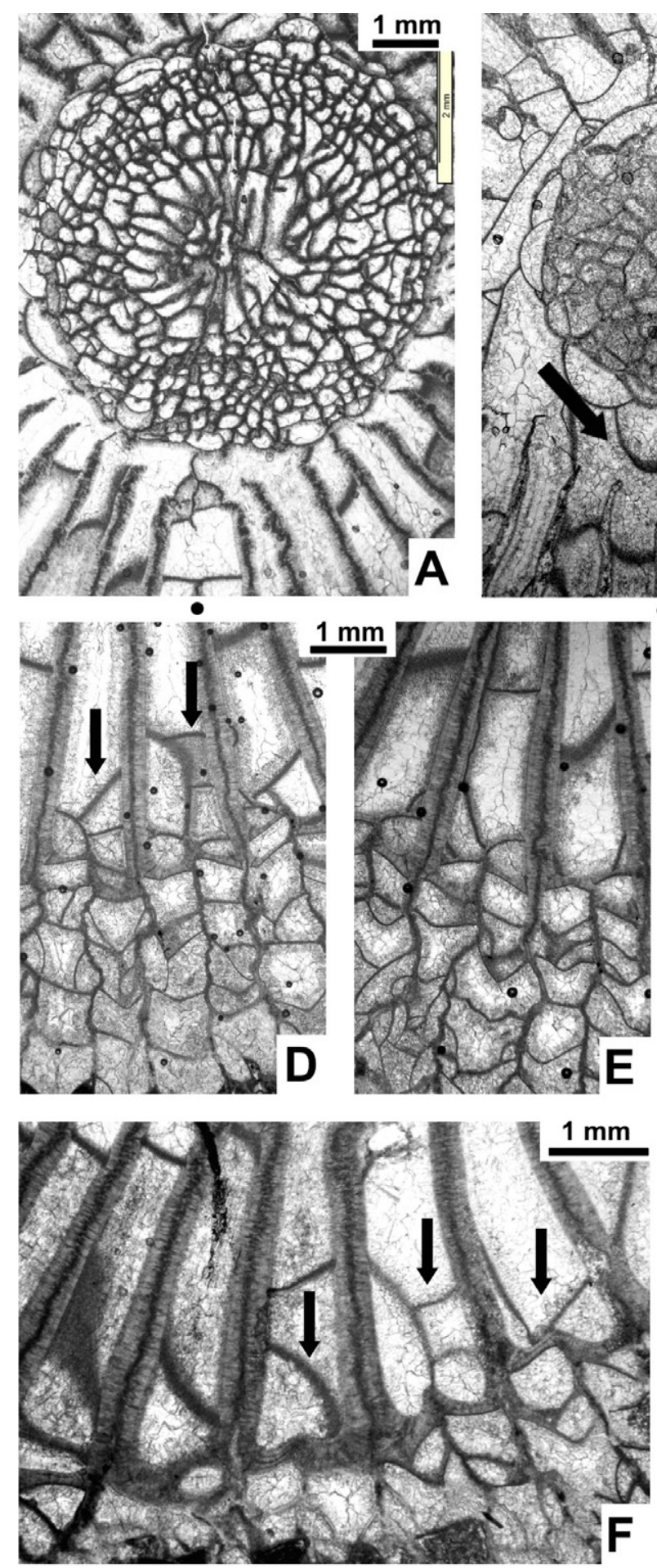

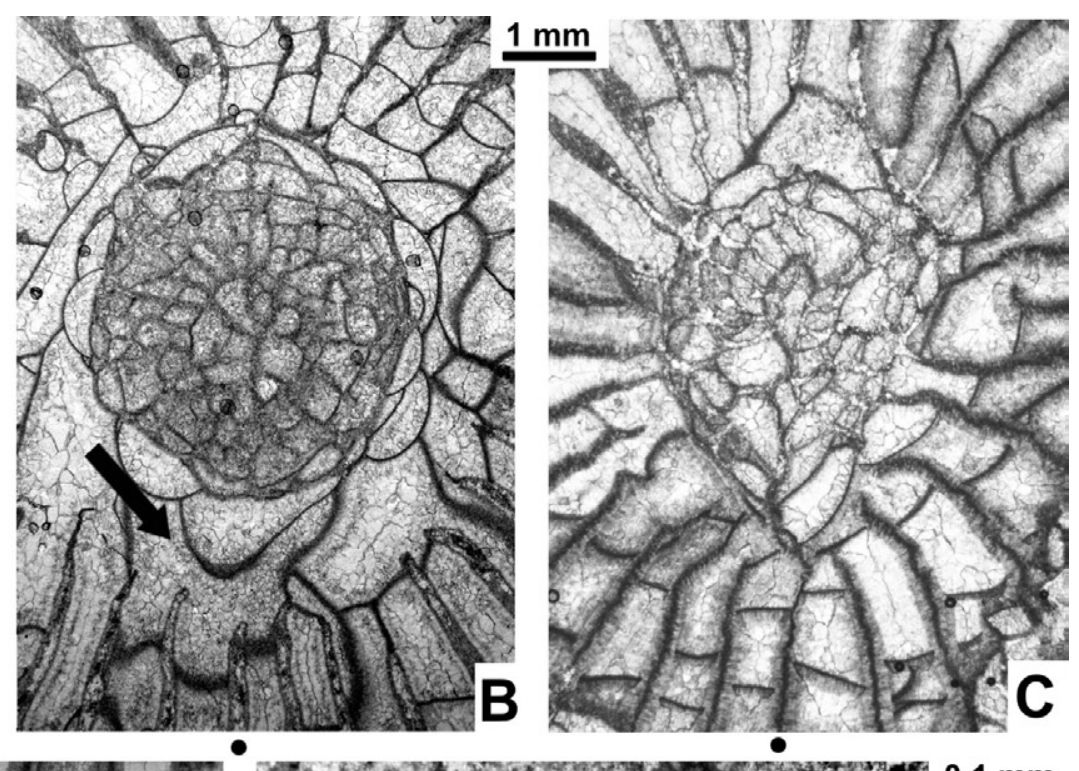

$\bullet$

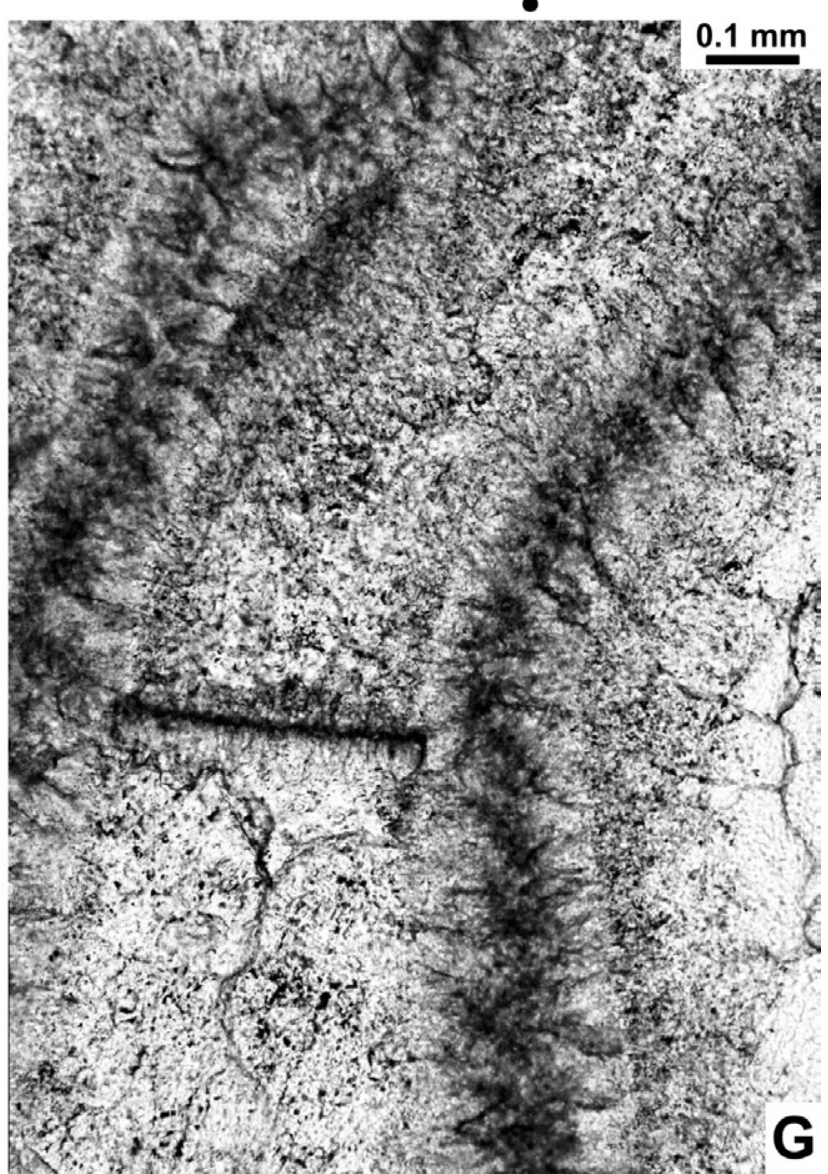

FIGURE 9 Heritschioides splendidus sp. nov. Holotype from sample SOB-F1. Details. Transverse sections, A-C) axial structures; A) mature growth stage; note thin, separated inner margin of cardinal septum (lower), B) advanced neanic growth stage; arrow points to sections of tabulae depressed into cardinal fossula, C) neanic growth stage - thin, wavy median lamella connected directly to cardinal septum; D-F) biform (arrows) and normal tabularium in transverse sections; $\mathrm{G}$ ) transverse section, bunches of crystalline fibrils that replaced trabeculae. 

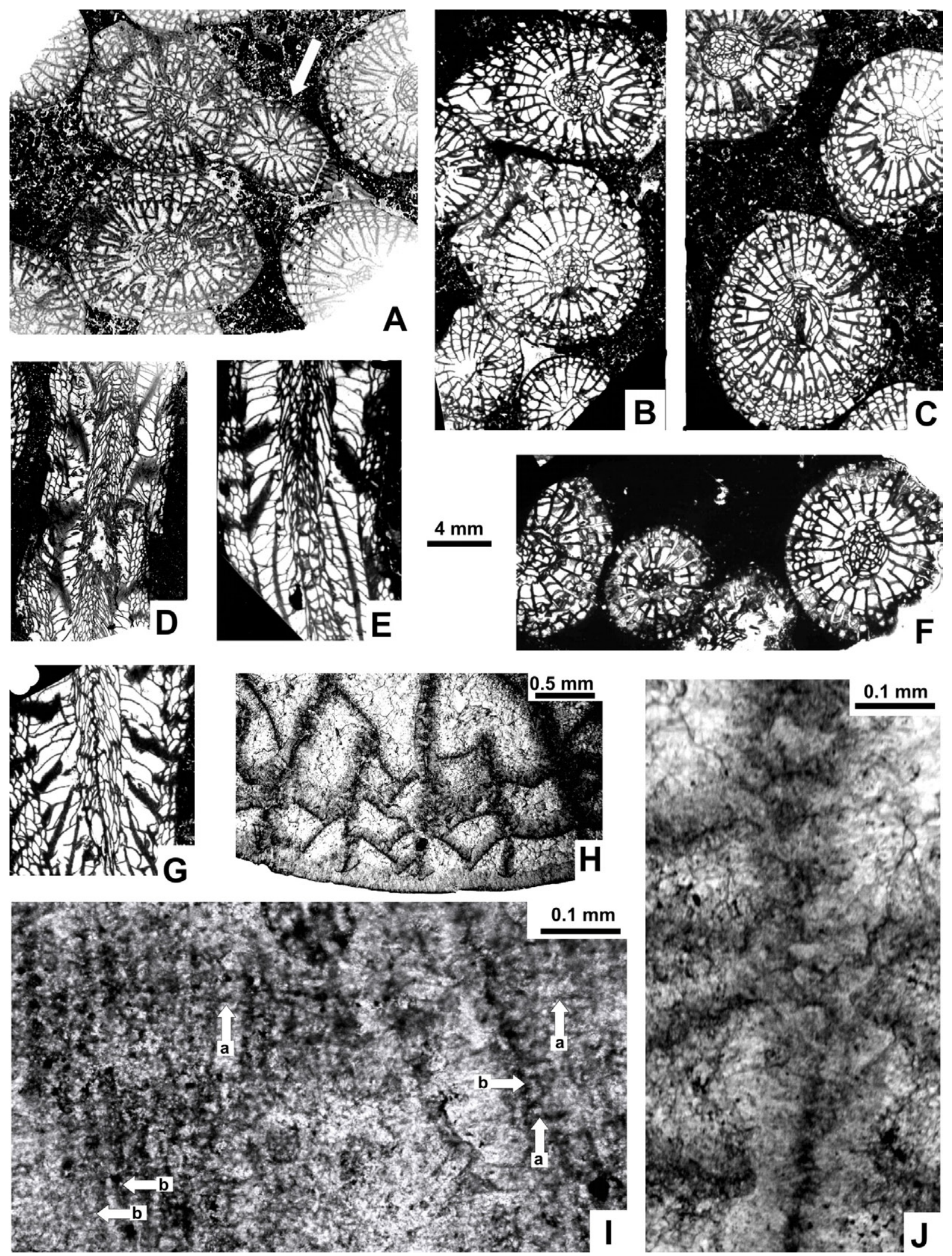

FIGURE 10 . Heritschioides alaskensis sp. nov., A-E, G-J) holotype from SMI 2004 \#4; F) paratype 1 from SMI 2004 \#3. Transverse section. A-C) Transverse sections. Arrow in A points to corallite illustrated in Figure 11J-M. D, E, G) Longitudinal sections. H) Enlarged from A to document biform morphology and very shallow penetration of septa into narrow external wall. I) Enlarged from D, longitudinal section showing trabecular microstructure; arrows with 'a' remnants of trabeculae, arrows with 'b' remnants of growth lines. J) Enlarged from A, bunches of fibrils (lower) are remnants of trabeculae, totally destroyed by diagenesis in remaining part of septum. Scale bar in the middle corresponds to all images, except where indicated. 
separating axial column from tabularium. In immature growth stages median lamella thin and wavy, connected with (Fig. 9C) or slightly elongated towards cardinal septum. At more advanced immature growth stage, median lamella, as in corallite shown in Figure 9B, occurs as thin plate or is absent, cardinal septum slightly shortened; presence of cardinal fossula documented by arrangement of sections of tabulae (Fig. 9B, arrow). Remnants of inner margin of cardinal septum or peripheral margin of median lamella represented by thin, wavy strip in cardinal fossula (Fig. 9A). Dissepimentarium composed of up to six or eight ranks of small, globose, irregular and concentric, interseptal dissepiments in major part of dissepimentarium; at maturity short bunches of small dissepiments, incipient pseudonaotic structures, attached obliquely to peripheral limits of septa. Lonsdaleoid dissepiments absent. Tabularium with biform morphology when minor septa extend into tabularium (Fig. 9D, arrows), normal in loculi where those septa restricted to dissepimentarium (Fig. 9E), both types may be developed next to one another (Fig. 9F, biform indicated by arrows). Tabularium (Fig. 8H-J) composed mostly of incomplete, upwardly arched tabulae inclined gently upward to axial column, $10-12 / \mathrm{cm}$. Boundary between dissepimentarium and tabularium marked by light stereozone thickening; boundary between tabularium and axial column sharp.

Microstructure variously altered diagenetically. Based on comparison with similar structures in septa of $\mathrm{H}$. kuiuensis sp. nov., bunches of crystalline fibrils in several septa (Fig. 9G), interpreted as trabeculae enlarged during recrystallization process at expanse of sclerenchymal sheets of septa.

Discussion. H. splendidus sp. nov. resembles H. kuiuensis sp. nov, but differs in having a narrower column, much larger corallites, having greater dilation of major septa in the tabularium, and lacking a recognizable median lamella in mature corallites. From H. columbicum (Smith, 1935) it differs primarily in the morphology of the axial column, which comprises both well developed normal and numerous extra septal lamellae, a shortened cardinal septum, an easily recognizable cardinal fossula in mature corallites, the lack of lonsdaleoid dissepiments and pseudonaotic septa, greater dilation of the major septa in the tabularium, and a hemispherical arrangement of tabellae in the axial column. The latter character also distinguishes it from $\mathrm{H}$. kuiuensis.

Occurrence. As for the holotype.

Heritschioides alaskensis FEDOROWSKI and STEVENS, sp. nov.

Figures 10, 11

Etymology. Named for the State of Alaska where the specimens were collected.

Holotype. USNM 545246 from sample SMI 2004 \#4.

Locality and age of the holotype. SMI 2004; Kuiu Island, Alaska. Moscovian in age.

Material. Holotype specimen listed above originally greater than $8 \mathrm{~cm}$ in diameter with four transverse and three longitudinal thin sections, and 20 peels; paratype 1, sample SMI 2004 \#3 with two transverse and two longitudinal thin sections; paratype 2, sample SMI 2004 \#5, with two transverse and one longitudinal thin section. Sample SMI 2004 F1 with six transverse thin sections and one longitudinal thin section questionably belongs to this species. See Appendix I for locality information.

Diagnosis. Heritschioides with $\mathrm{n}: \mathrm{d}$ value $=26: 9.0 \mathrm{~mm}$ to 26:12.0mm; axial column with obscure or no median lamella occupies 1/4-1/3 corallite diameter; major septa somewhat dilated in tabularium; minor septa penetrate tabularium with slightly dilated margins; biform tabularium recognizable in many septal loculae; lonsdaleoid dissepiments absent.

Description. External wall about $0.1-0.2 \mathrm{~mm}$ thick. Maximum corallite diameter 13mm; $\mathrm{n}: \mathrm{d}=19: 6.0-7.0,22: 8.9,23: 10.0,24: 9.0$, 26:9.0-12.0. In transverse sections (Fig. 10A-C, F) major septa penetrate very slightly into external wall or appear to be attached to it (Fig. 10H), commonly approach axial column, rarely continuous with septal lamellae, thin in dissepimentarium, slightly dilated in tabularium, distal ends tapering to blunt. Cardinal septum rarely and indistinctly shortened; more commonly equal in length to adjacent major septa, may join median lamella when one present. Cardinal fossula lacking. Minor septa commonly penetrate short distance into tabularium where inner margins dilated. Axial column continuous, one third to one-fourth corallite diameter, isolated by vertical lateral tabellae and up to five or more ranks of steeply dipping, elongate axial tabellae. Septal lamellae variable, representing most major septa in some corallites, few in others. Extra septal lamellae extremely rare, recognizable in some mature corallites. Median lamella commonly lacking, obscure when present. Dissepimentarium commonly one-third corallite radius, generally composed of three or four ranks of small, globose dissepiments as seen in longitudinal section (Fig. 10D, $\mathrm{E}, \mathrm{G})$; in transverse section dissepiments variable in size and shape: concentric, irregular and pseudoherringbone; lonsdaleoid dissepiments absent. Tabularium composed of complete and incomplete, slightly convex upward tabulae that rise moderately steeply upward to axial column. Biform morphology recognizable mainly in transverse sections, indicated by different arrangement of peripheral parts of tabulae (Fig. 10H). Very light stereozone developed at margin of tabularium. Boundary between tabularium and axial column sharp.

In transverse sections of septa (Fig. 10J) septal microstructure diagenetically altered into irregular bunches of crystalline fibrils; in longitudinal sections ultrastructure totally destroyed, but altered intersecting growth lines and rods interpreted as remnants of fine trabeculae (Fig. 10I, arrows with letters 'b' and 'a', respectively) are preserved.

Blastogeny (Fig. 11A-M) investigated in two series of acetate peels from two offsetting corallites in holotype (Fig. $11 \mathrm{~A}-\mathrm{I}$ and $11 \mathrm{~J}-\mathrm{M}$, respectively). Earliest phase of offsetting in 
one offset diagenetically destroyed. Offsetting in more complete specimen begins with formation of narrow space for offset within dissepimentarium of parent (Fig. 11A-C). Minor septa and dissepiments disappear from loculi between three major septa becoming separated into unequal segments: long inner segments with strongly thickened peripheral margins retained in parent; short, thin peripheral segments forming initial skeleton of offset attached to external wall in offset. Neosepta appear early at external wall in offset, suggesting peripheral segment of parent's middle septum of offset becomes cardinal septum in offset. Its thin, tabula-like inner part extends far beyond offset's axis (Fig. 11A-H, arrow). Cardinal septum in second offset intersects its lumen early in hystero-ontogeny (Fig. 11J, arrow), soon reduced to length of adjacent major septa (Fig. 11K, arrow), elongates again to reach elongated counter septum (Fig. 11L, arrow).
Development of counter septum differs in two offsets studied; hardly identifiable in first offset (Fig. 11G-I), long in second (Fig. $11 \mathrm{~K}-\mathrm{M})$; in both counter septa inherited from same middle major septum of parent corallite. Thus, both protosepta are atavosepta.

Alar septa of both offsets inherited from two of parent's major septa, one on each side of major septum that gave rise to offset's protosepta located in offset's peripheral wall from beginning of offsetting process (Fig. 11A, B, dots), clearly marked by being longest septa in cardinal quadrants and by short septa in counter quadrants adjacent to them (Fig. 11D-H, K, dots).

Increase in number of offset's septa in part common with parent camouflaged by both long-lasting thickening of skeletal
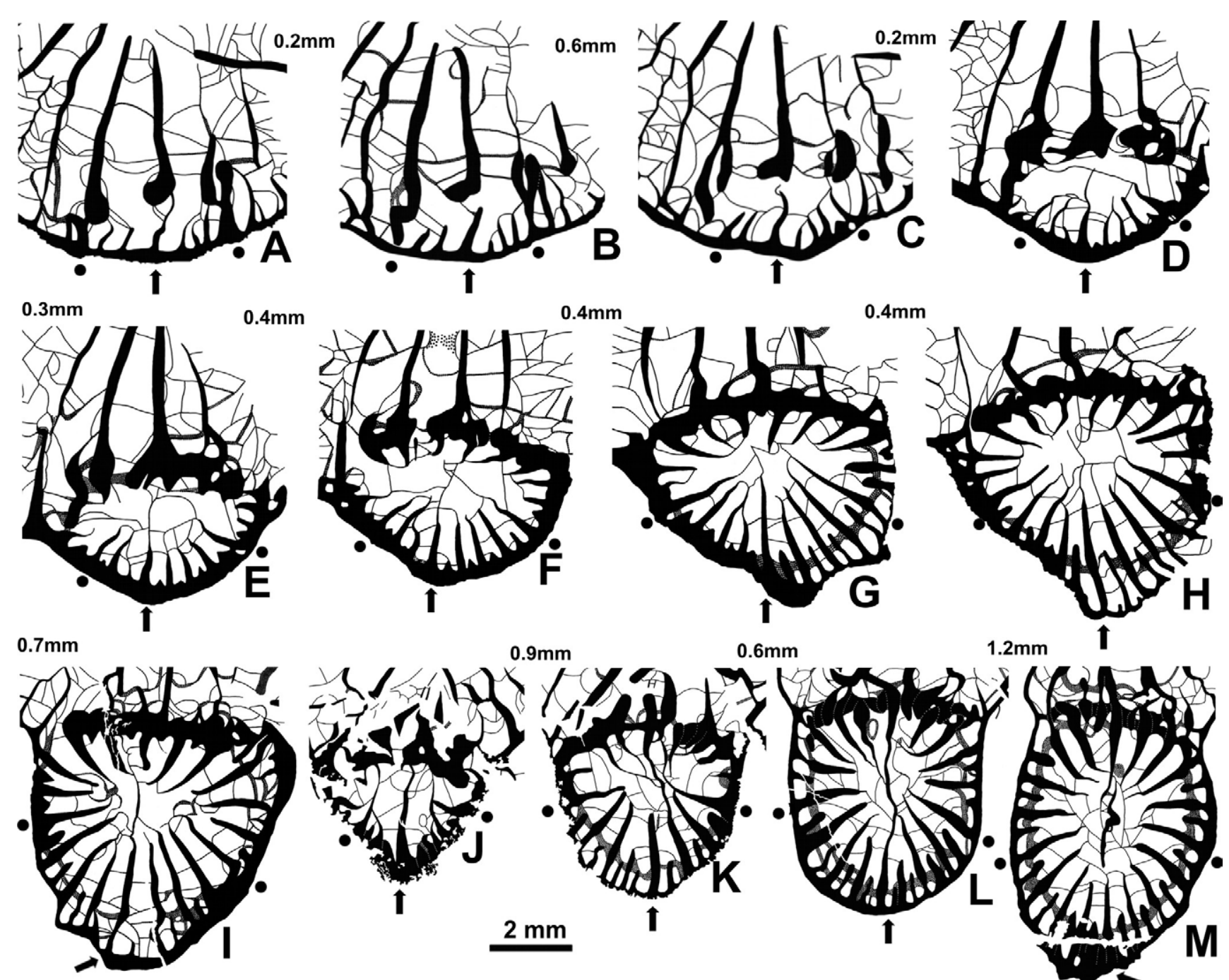
$1.2 \mathrm{~mm}$

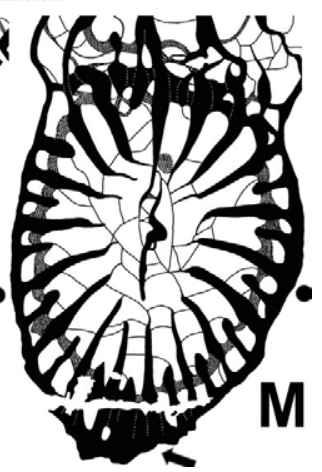

FIGURE 11 Heritschioides alaskensis sp. nov. Holotype from SMI 2004 \#4. Blastogeny of two offsets based on serial peels spaced as indicated. First corallite: A-D) hystero-brephic growth stage; E, F) early hystero-neanic growth stage; G-I) hystero-neanic growth stage. Second corallite: J) early hystero-neanic growth stage; K, L) neanic growth stage; M) late neanic/early mature growth stage. Scale bar at bottom applies to all figures. Arrow points to cardinal septum; dots indicate position of alar septa. 
elements and formation of partition composed of short thickenings corresponding to major and minor septa. Shortest major septa adjacent to alar septa indicate septal insertion typical for Rugosa; details unknown.

Insertion of minor septa (Fig. 11D, E) appears cyclic because they arise in offset's lumen at approximately same level of growth, but apparently inserted in series having earlier been hidden in thick external wall. Dissepimentarium follows appearance of minor septa; best developed in cardinal quadrants in both offsets.

Development of axial structure forms main difference between two offsets. In last preserved growth stage of first offset, only a very long cardinal septum, slightly thickened in axial part and extending beyond offset's axis; counter septum attached to it by a tabula (Fig. 11I). In second offset counter septum elongated beyond corallite axis, joining major septum right of cardinal septum; later joining cardinal septum for short period (Fig. 11L). Later counter septum free, still extends to offset's axis (Fig. $11 \mathrm{M})$. Long, curved, axially thickened median lamella, free from both protosepta (Fig. 11M), preceded by temporary presence of axial septum.

Blastogeny of two offsets differs in development of counter septum; similar in all other details. Cardinal septum participated in formation of median lamella in both instances, being dominant in first offset. Inconsistent length of protosepta is typical for genus.

Discussion. This species resembles H. columbicum, the type species of the genus, in the similar arrangement of axial tabellae in the axial column, in that the minor septa penetrate the tabularium, and in having rare extra septal lamellae appearing late in the hystero-ontogeny. The type species, however, has much greater $\mathrm{n}: \mathrm{d}$ values, a wider, more complex dissepimentarium with lonsdaleoid dissepiments common, and pseudo-naotic structures well developed. H. splendidus sp. nov. differs primarily in having much larger n:d values, much denser axial column with many extra septal tabellae and a shortened cardinal septum located in a tabular cardinal fossula. The present species differs from $\mathrm{H}$. kuiuensis sp. nov. in the smaller size of the corallites, a narrower, less complex axial column with extremely rare extra septal lamellae if any, and with longer minor septa. Corallites of this species differ from $\mathrm{H}$. separatus sp. nov. in the smaller diameters of the corallites, the minor septa penetrating the tabularium, and in the major septa closely approaching the axial column in most corallites (see below).

\section{Occurrence. As for the holotype.}

Heritschioides separatus FEDOROWSKI and STEVENS, sp. nov.

\section{Figure 12}

partim 1972. Corwenia jagoensis Armstrong, 1972, p. 10, pl. 4, fig. 3 and pl. 5, figs. 3-4 only.
Etymology. Latin separatus - separated, distant. Named for its morphological and taxonomic difference from the holotype of Corwenia jagoensis Armstrong, 1972.

Holotype. USNM 161040.

Locality and age of the holotype. Stratigraphic section 60C-201, near Salisbury Mountain, about $1.5 \mathrm{~m}$ below the top of the Wahoo Limestone (see Armstrong, 1972). Associated microfossils (Armstrong, 1972, p. 13) indicate an Atokan (Bashkirian) age.

Material. Only the holotype colony, considered by Armstrong (1972) as a paratype of his species Corwenia jagoensis (see discussion below). Three transverse thin sections made and illustrated by Armstrong (1972, pl. 4, fig. 3 and pl. 5, figs 3-4) and two well oriented longitudinal thin sections made by the second author were available for the study. All of Armstrong's transverse thin sections and the newly made longitudinal thin sections are illustrated here. Neither the blastogeny nor the microstructure of septa were studied. Although figure 2 on pl. 5 in Armstrong (1972) is labeled as belonging to the same colony as the other figures, the section is so different from those made by one of the writers (Calvin Stevens), we suspect that it actually was derived from another colony.

Diagnosis. Heritschioides with extreme n:d values 34:20 and $31: 24 \times 20 \mathrm{~mm}$; thin major septa do not penetrate axial structure; minor septa restricted to dissepimentarium which occupies up to $1 / 3$ corallite radius; cardinal septum may reach simple axial structure with median lamella obscure or absent; septal lamellae much smaller in number than major septa; extra septal lamellae absent or very rare; row of lateral tabellae in axial column incomplete; small lonsdaleoid dissepiments may occur.

Description. Corallites densely packed, but crowding increased by compaction as demonstrated by broken peripheral skeletal elements in some neighboring corallites (Fig. 12C, arrow). $\mathrm{N}$ : $\mathrm{d}$ values of early mature and mature corallites as in diagnosis and 30:21, 29:16.3, 29:15.6, 28:16; juvenile growth stages not observed. Major septa almost equal in length, rarely approach axial column in early mature corallites, slightly and equally thickened in tabularium, thin in dissepimentarium. Cardinal septum varies from slightly shortened to penetrating axial structure. Cardinal fossula barely recognizable or absent. Minor septa thin, restricted to dissepimentarium, some interrupted by small lonsdaleoid dissepiments. Axial structure in transverse section weak, occupies less than $1 / 3$ corallite diameter, less than $1 / 4$ in some. Thin median lamella hardly recognizable or absent. Septal lamellae thin and irregular, far fewer than number of major septa. Extra septal lamellae absent from all thin sections studied. Axial column in longitudinal section well developed, incompletely separated from tabularium; lateral tabellae absent from some parts of axial column. Tabulae mostly incomplete, some enter column. Tabellae steeply elevated adaxially near axial column, commonly anastomosing at periphery. Unquestioned biform tabularium not observed. Dissepimentarium 1/4 corallite radius in small specimens to slightly more than $1 / 3$ in largest. 

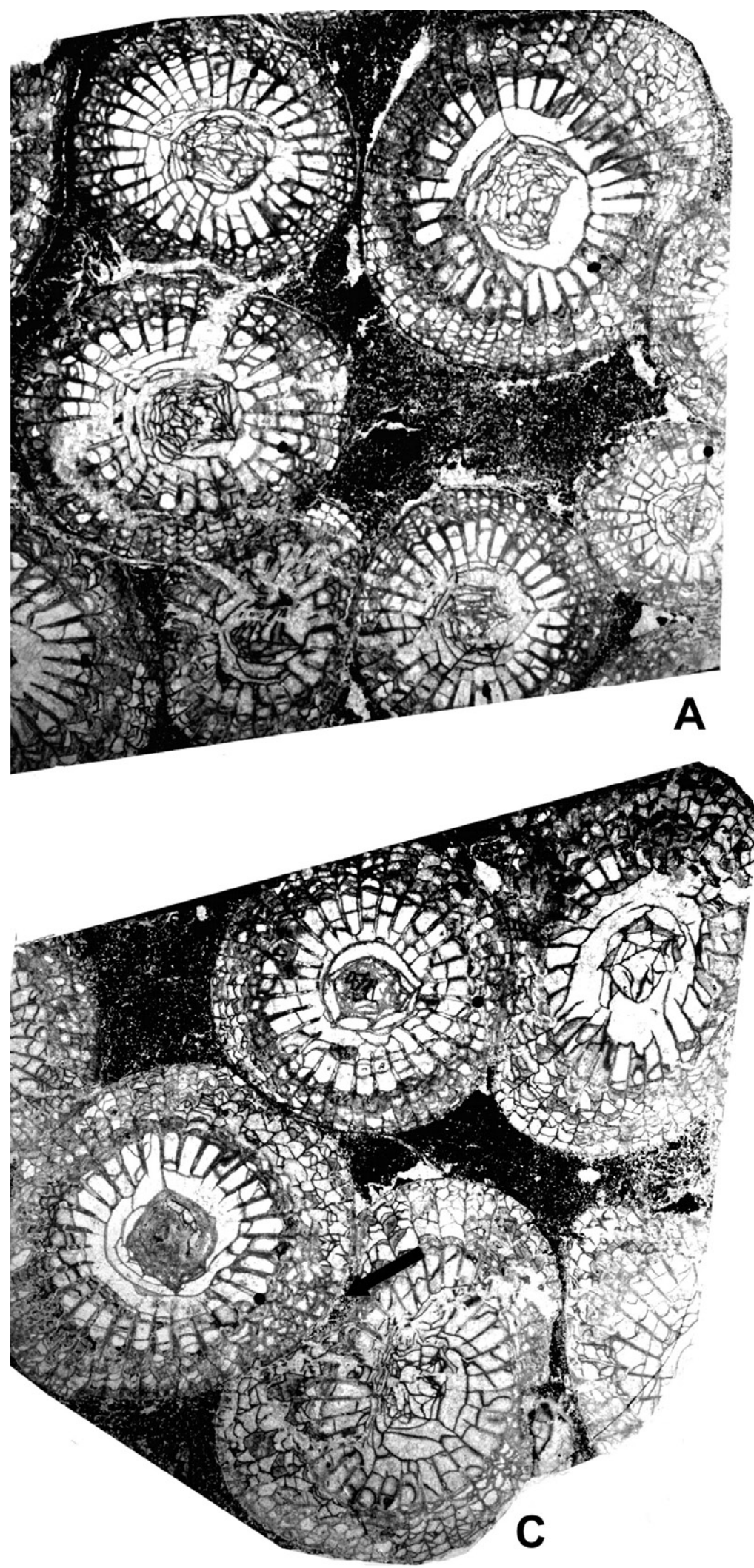
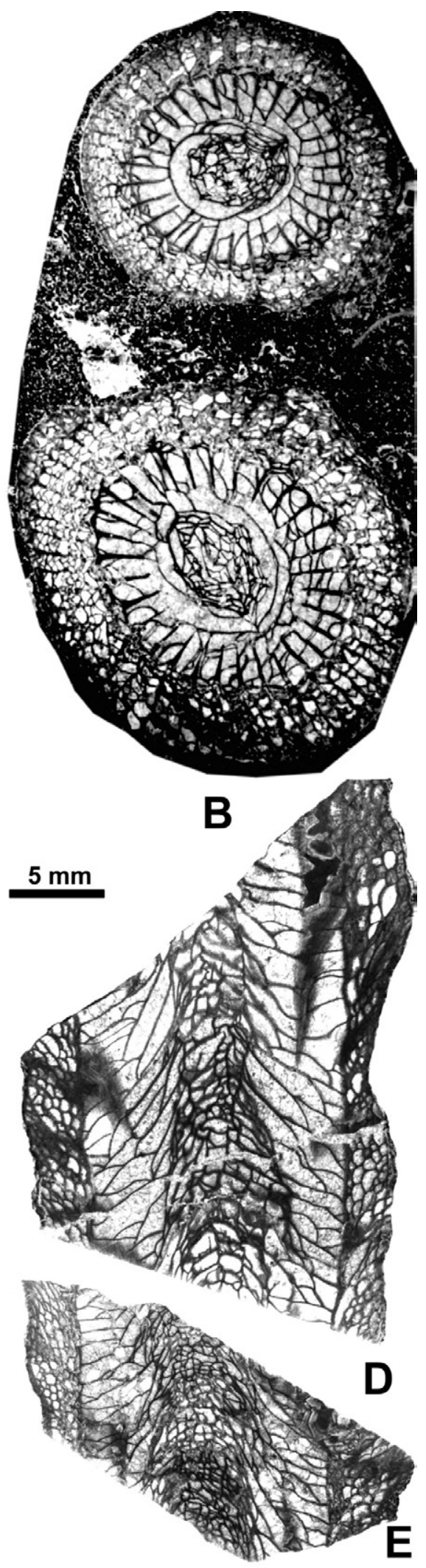

FIGURE 12 Heritschioides separatus sp. nov. Holotype USNM 161040, A-C) transverse sections illustrated by Armstrong (1972, pl. 4, fig. 3; pl. 5 , figs. 3,4 ) as paratype of his species Corwenia jagoensis. Arrow in C points to part of corallite squashed by compaction, D, E) new longitudinal sections documenting continuous axial column. Scale bar in the middle corresponds to all images. 
Dissepiments small, most rectangular and irregular, rarely pseudoherringbone and/or lonsdaleoid; incipient pseudonaotic structures common at periphery of largest corallites.

Discussion. Corwenia jagoensis Armstrong, 1972 comprises colonies belonging to different genera. Its holotype and most paratypes do not belong in Corwenia, but they also differ from Heritschioides. The paratype USNM 161040, the only exception, is here re-investigated. This coral was recognized as somewhat similar to Heritschioides by Armstrong (1972, p. 13), who characterized it as follows: "Thus, of all the specimens, it shows the closest relationship to the genus Heritschioides Yabe", which Armstrong accepted as a Permian taxon. We accept that relationship, but it is now known that the type species for the genus is late Serpukhovian-early Bashkirian in age and all other species of Heritschioides are middle Carboniferous rather than Permian (Fedorowski et al., 2007).

We do not make an attempt here to revise "Corwenia" jagoensis formally, but later we do plan to revise those specimens included in C. jagoensis, which are comparable to colonies from Kuiu Island. The Atokan (Bashkirian) "paratype" USNM 161040, re-described by us here as Heritschioides separatus sp. nov., possesses some of the largest corallites with the simplest axial structure among the species assigned to this genus. It also possesses fewer septal lamellae than the number of major septa, and apparently lacks extra septal lamellae. Both the large size and the simple axial structure are adequate for distinguishing this species from all remaining members of the genus.

Occurrence. As for the holotype.

GENUS Kekuphyllum FEDOROWSKI and STEVENS, gen. nov.

Type species: Kekuphyllum sandoense FEDOROWSKI and STEVENS, sp. nov.

Etymology: Named for Keku Strait separating Kuiu Island, Alaska, from other islands to the north.

Locality and age: USGS locality 21334-PC. Saginaw Bay Formation, probably Moscovian.

Diagnosis: Cerioid-aphroid; partitions rarely interrupted; median lamella monoseptal, derived from axial septum or cardinal septum alone, may remain continuous with it; most septal lamellae normal; extra septal lamellae occasional; axial column continuous; tabularium weakly biform when minor septa elongated; tabulae incomplete.

Discussion. Heritschioides is the only genus presently included in the Subfamily Heritschioidinae, although Copia Vassilyuk and Kosyreva, 1974 is here conditionally included in that subfamily. The fasciculate growth form of those genera is diagnostically important enough for the distinction between them and the cerioid-aphroid Kekuphyllum gen. nov. Thus, we concentrate on similarities supporting the inclusion of Kekuphyllum in the Heritschioidinae rather than on differences. The early hystero- ontogeny is crucial in that respect. The following characters are most important for the subfamily identification of Kekuphyllum (Figs. 13-15): 1. either the axial septum or the elongated cardinal septum occurs at an early growth stage; 2 the median lamella of the axial structure is derived from those septa, 3; lamella extending towards the cardinal septum, commonly intersects all or most of the axial structure. 4. rare extra septal lamellae appear in axial structures of some corallites; and 5. the continuous axial column closely resembles that in Heritschioides. All those characters are common to species of Heritschioides and all point to the Family Aulophyllidae.

Kekuphyllum is the only massive colony included in the Subfamily Heritschioidinae so far, but two species of Gorsky (1938), Lonsdaleia (Wentzelella) diversa and L. (W.) multivesiculosa from the so-called Barents Series of Novaya Zemlya, may belong to Kekuphyllum. We do not suggest that relationship in a formal way because several important characters of Gorsky's specimens, such as the microstructure of the intercorallite walls, the early blastogeny, and the occurrence of extra septal lamellae are unknown from his specimens and are not recognizable in his illustrations. Only the latter character may be suspected to occur in L. (W.) multivesiculosa judging from Gorsky's (1938, p. 120) expression "large number of tabulae intersections", which may refer to septal lamellae. Besides, Gorsky (1938) suggested a Late Carboniferous (in the Russian three partite scale). Thus, his species may be Gzhelian or even Permian in age. Revision of those species and establishment of their stratigraphic occurrence is needed prior to making a final decision of their true relationship to K. sandoense on a generic level. The continuous axial column, lack or very weak development of a cardinal fossula with the cardinal septum slightly shortened in some corallites (Fig. 13F) and the cerioidaphroid growth form of $\mathrm{K}$. sandoense are important characteristics to be considered for comparison with the Novaya Zemlya species after they are revised.

Kekuphyllum sandoense FEDOROWSKI and STEVENS, sp. nov.

Figures 13-15

Etymology. Named for the late well known coral expert William J. Sando who provided the specimen for study.

Holotype. USNM 545243 from sample USGS 21334-PC \#2

Locality and age of the holotype. USGS locality 21334PC, Kuiu Island, Alaska; Saginaw Bay Formation, probably Moscovian in age.

Material. Type specimen listed above consisting of several large fragments apparently from one corallum originally at least $18 \mathrm{~cm}$ in diameter with eleven transverse and seven longitudinal thin sections and 73 acetate peels. See Appendix I for locality information.

Diagnosis. Kekuphyllum with maximum n:d value 28:9.5 

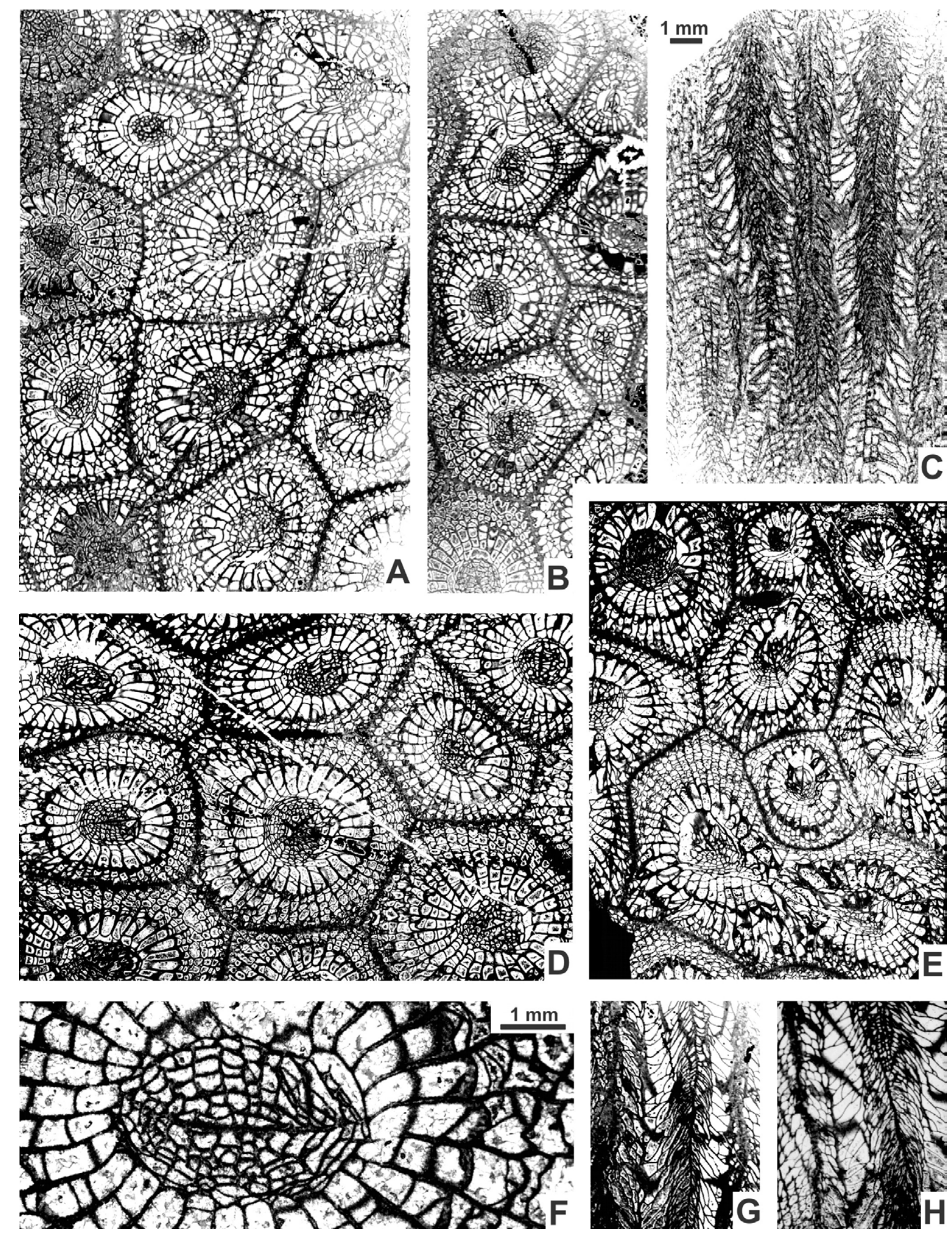

\begin{tabular}{l|l}
\hline FIGURE 13 & Kekuphyllum sandoense sp. nov. Holotype 21223-PC \#2. Ma \\
tions. Scale bar in the upper right corresponds to all images, except F.
\end{tabular} 
and 28:11.2mm; minor septa rarely slightly enter tabularium; lonsdaleoid dissepiments occur in corallite corners.

Description. Corallum cerioid-aphroid. Partitions mostly continuous, about $0.3 \mathrm{~mm}$ thick between peripheral margins of septa, much thicker when septa laterally contiguous (Fig. 14D, F). Rarely observed interruptions (channels) terminate gently, closed by dissepiments arranged in rows perpendicular to partition and parallel to one another (Fig. 14A, arrow) or filling in inter-corallite channels between partitions (Fig. 14C, arrow); sharply ended interruptions of partitions (Fig. 14B) due to diagenesis. Two adjacent corallites similar in size indicating twins may merge (Fig. 13B, upper; E, lower) for some unknown reason. Completely isolated corallites polygonal, diameter at maturity 7-11.2mm; n:d values $=20-21: 4.0 \mathrm{~mm}, 23: 5-7 \mathrm{~mm}$; 25-26:10.0mm, and maximum as in Diagnosis (Fig. 13A, B, D, E). Major septa long with peripheral margins thickened up to lateral contiguity with minor septa in some (Fig. 14E, F), some closely approach axial column, others may be continuous with septal lamellae, many free-ended, thin in dissepimentarium, slightly thickened at outer margin of tabularium, then tapering toward axial column. Counter septum indistinguishable from other major septa, rarely attached to slightly thickened median lamella with wavy and strongly tapering inner margin, free from median lamella in most. Counter septum not dominant even when continuous with median lamella. Cardinal septum of variable length: slightly shortened, equal to adjacent major septa, or extending to median lamella; axial structure points towards that septum when shortened (Fig. 13F). Minor septa vary in length, most confined to dissepmentarium, few penetrate outermost tabularium, some discontinuous. Cardinal fossula lacking in most, inconspicuous and does not penetrate dissepimentarium when present. Axial column prominent, continuous (Fig. 13C, G, H), from less than $1 / 2$ to slightly more than $1 / 3$ corallite diameter, composed of simple median lamella, numerous septal lamellae, including rare extra lamellae, and up to six rows of steeply dipping, very elongate axial tabellae; lateral tabellae numerous. Boundary between tabularium and axial column mostly distinct. Tabularium commonly normal. Incipient biformity indicated mainly by sections of tabulae
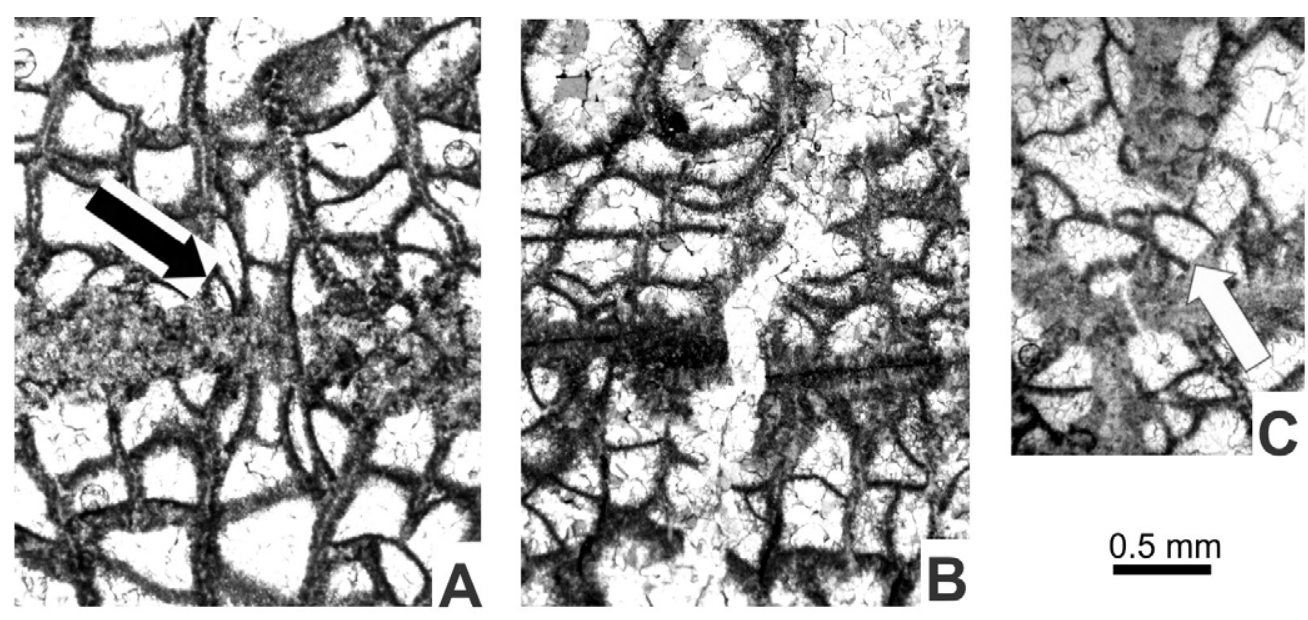

\section{$\underline{0.5 \mathrm{~mm}}$}
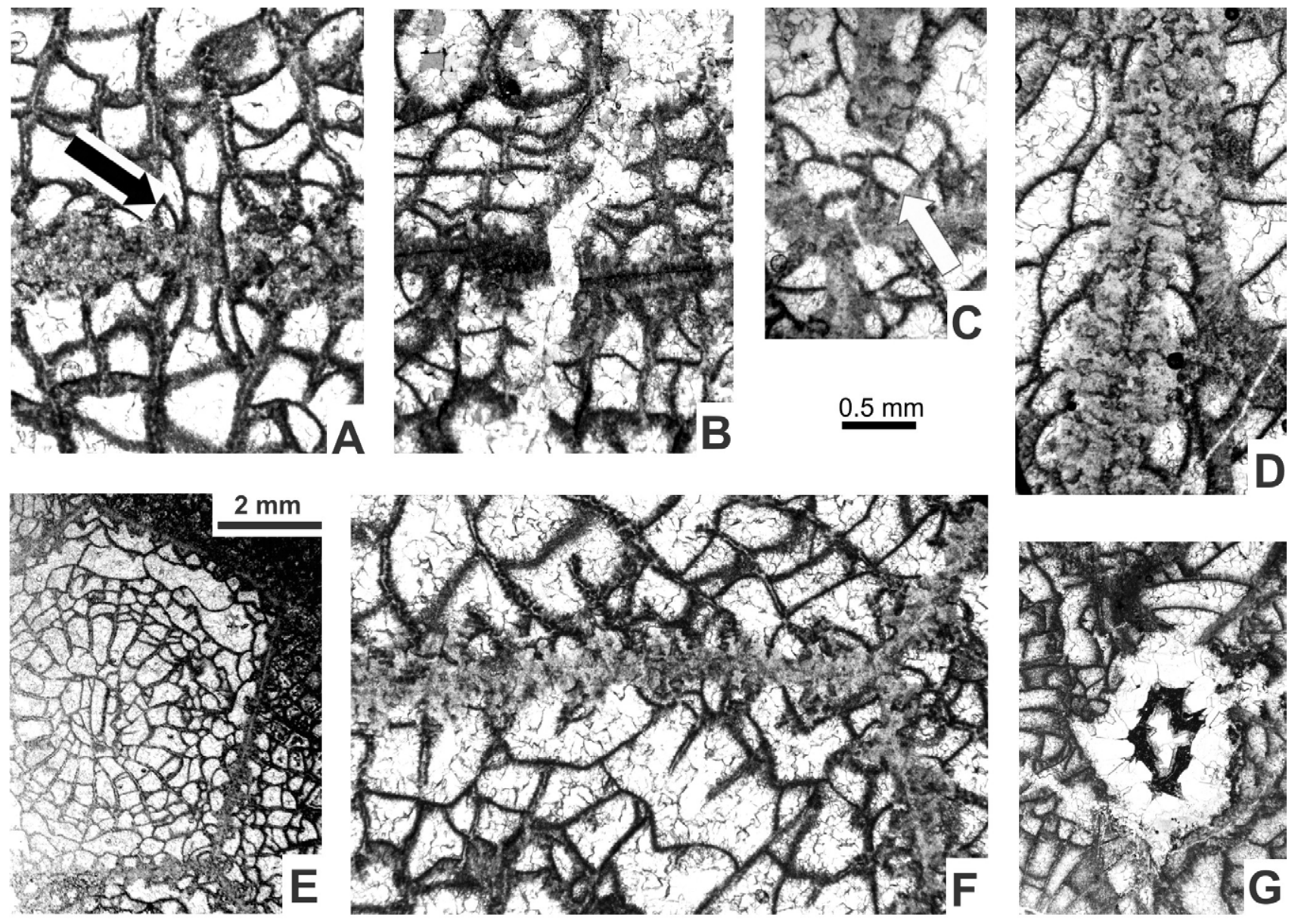

FIGURE 14 Kekuphyllum sandoense sp. nov. Holotype 21223-PC \#2. Details, A-C, E-G) transverse sections. A, C) Channels, shown by arrows, overgrown by dissepiments as suggested by their arrangement. B) Diagenetically caused break imitating intercorallite channel. D, F) Morphology of partition (D: Iongitudinal, F: transverse section). E) Lonsdaleoid dissepiments extremely well developed. G) Chert replacing skeletal elements of a corallite. Scale bar in right middle applies to all images except $\mathrm{E}$. 
attached to inner margins of some longest minor septa; may be observed in longitudinal sections (Fig. 15E, arrow and above it). Tabulae steeply inclined up to axial column, commonly seven or eight $/ 5 \mathrm{~mm}$, commonly incomplete with peripheral and periaxial tabellae, rarely complete. Dissepimentarium about one-third corallite radius, composed of two- to several ranks of small irregular and concentric, globose dissepiments with lonsdaleoid dissepiments present at corners of several corallites; may extend around almost entire corallite in some (Fig. 14E). Pseudonaotic septa occur in several corallites. Sclerenchyme thickening at inner row of dissepiments common.
Blastogeny was investigated in several offsets of holotype. Diagenetic alteration, however, has limited the precision of the descriptions and drawings of series of acetate peels that were made.

Earliest growth stage observed (Figure 15A) closely comparable to species of Heritschioides. Septa divided into thin external segments inherited by offset and attached to external wall and inner segments retained in parent corallite, peripheral margins of which strongly thickened at parent/offset boundary. Axial septum of offset directly connected to middle thickened

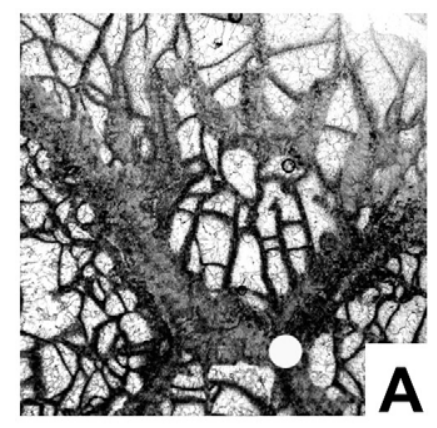

$1 \mathrm{~mm}$
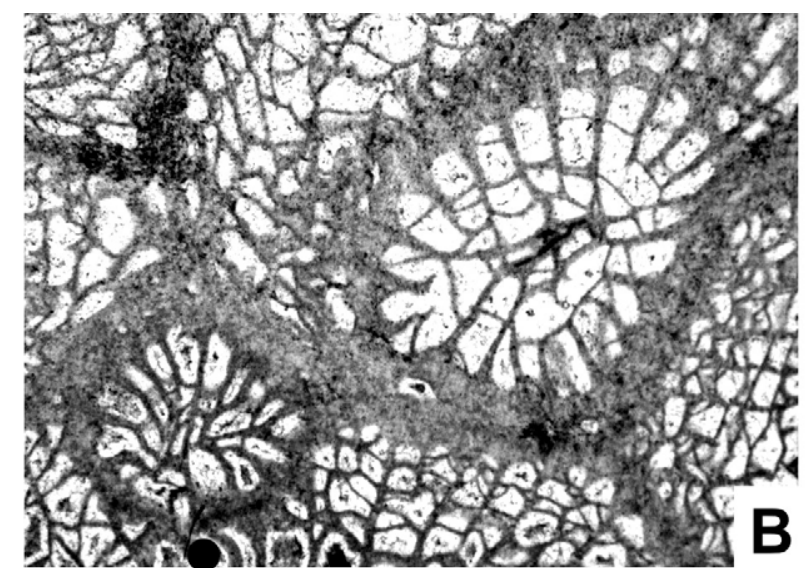

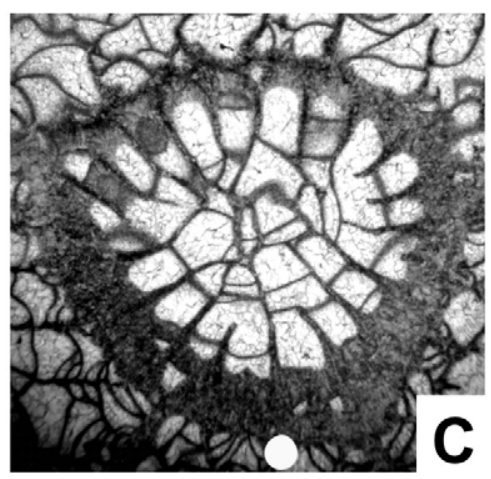
B
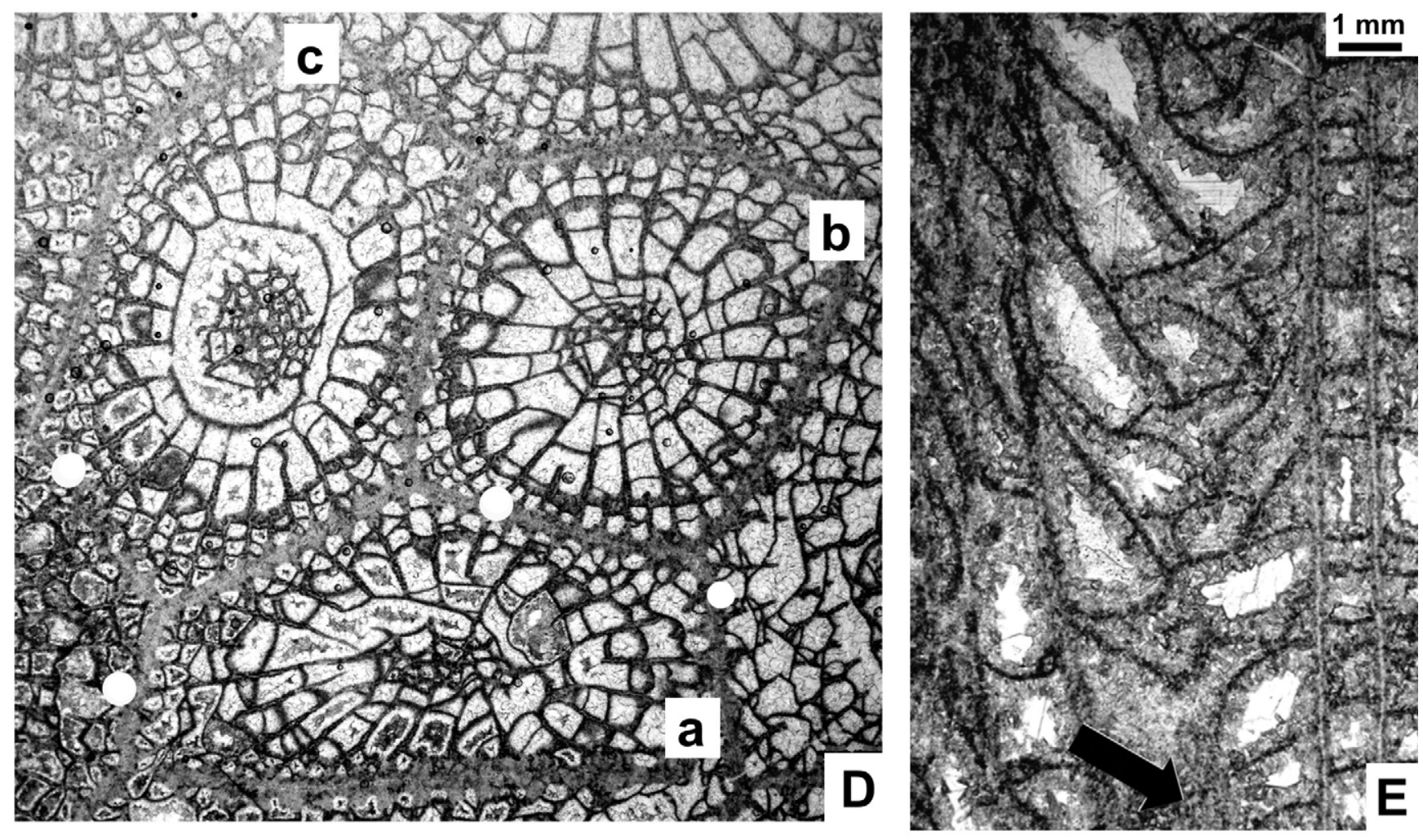

FIGURE 15 Kekuphyllum sandoense sp. nov. Holotype 21223-PC \#2, A-D) transverse sections. A-C) Offsets in early hystero-ontogenetic growth stage. D) Offsets in advanced growth stage. Letters correspond to description in text. E) Longitudinal section. Arrow points to biformly curved tabula. Scale bar in upper left corresponds to all images except E. 
septum of parent. Continuous axial septum retained in hysteroontogenetically more advanced offsets (Fig. 15B, lower left; C). Arrangement of major septa suggest cardinal septum in offset formed from peripheral segment of axial septum (Fig. 15C, white dot); arrangement of septa in offset and its symmetry irregular; recognition of axial septum relative to position of cardinal septum; uncertain in some (Fig. 15B, upper offset).

Three adjacent immature corallites separated by partitions (Fig. 15D) all have minor septa, which penetrate tabularium, and complete dissepimentaria. Hystero-ontogenetically youngest corallite (Fig. 15D, corallite ' $a$ ' cardinal [left] and counter septa marked by white dots) possesses thin, inconspicuous median lamella connected to curved inner margins of both protosepta; some major septa unite with their lamellae in axial structure. In corallite intermediate in advancement in hystero-ontogeny (Figure 15D, corallite 'b') cardinal septum (marked by white dot) directly connected to slightly thickened median lamella to which most major septa unite. Most advanced corallite in hystero-ontogeny (Fig. 15, corallite 'c', cardinal septum marked by white dot) possesses axial structure completely separated from inner margins of major septa with free, slightly thickened median lamella which points towards shortened cardinal septum shown by short intercept attached to section of a tabula. Differences develop in corallites of any growth stage as indicated by both illustrated (Fig. 13A, B, D-F) and non-illustrated corallites.

Discussion. Being the only species of the genus known so far, K. sandoense does not require discussion other than that of the genus. The only existing taxa similar to our species are pointed out in that discussion.

Occurrence. As for the holotype.

\section{SUMMARY}

Recent studies on the Genus Heritschioides and genetically related and/or morphologically similar taxa (Fedorowski et al., 2007; Kawamura and Stevens 2012; present paper) allow some introductory conclusions. These studies show that the stratigraphic position of all representatives of the genus Heritschioides described so far is much older (Fedorowski et al., 2007; Kawamura and Stevens, 2012) than previously thought. The type species, H. columbicum (Smith, 1935), is not Permian, but late Serpukhovian/early Bashkirian in age, thus being the stratigraphically oldest species of the genus. Other species are younger, upper Bashkirian to Moscovian in age. Thus, the genus can be considered characteristic for these ages.

Also almost all species of Heritschioides occur in accreted terranes. H. separatus sp. nov. known from the Atokan (Bashkirian) strata of the Brooks Range is the only exception recognized so far. Such a distribution suggests that this genus originated on the northern margin of the North American Craton in the general vicinity of the Brooks Range or on oceanic platforms to the west or northwest. In addition the distance between those platforms and the cratonal shelf in Alaska must have been short enough for corals in the middle Carboniferous to migrate from one locality to another. Finally the complex nature of structures (as in Kekuphyllum) described here also tends to suggest a subtropical to tropical climate.

The detailed study of the protocorallite developed inside the colony of $\mathrm{H}$. kuiuensis allows a comparison of the ontogeny to the hystero-ontogeny, a kind of study not previously conducted. The ontogeny leaves no doubt as to the close relationship of Heritschioides to the Family Aulophyllidae. In addition, the hystero-ontogeny characteristics of Heritschioides and Kekuphyllum sandoense, although slightly different in details, are different from that of other genera in the Aulophyllidae, indicating the necessity for a separate subfamily status of those two genera.

\section{ACKNOWLEDGMENTS}

The authors wish to thank the Ebro Water Authority (CHE) for giving access to hydrochemical and other data used in this study. We would like to thank particularly the gentle help and support from Dr. Miguel Ángel García Vera, Felipe Delgado, Teresa Carceller and Vicente Sancho-Tello. We thank Dr. Pedro Lucha, who assisted with the fieldwork and made interesting contributions in the first steps of the project. We also thank Mr. José Ángel Navamuel (Zaragoza Municipality) for helping us to obtain permits to sample water from wells. The assistance of Enrique Oliver with some of the analytical determinations is also gratefully acknowledged. EBRONAUTAS SLL has handed over the cataraft used in the sampling survey. Dr. Acero and Dr. Asta have received economical support from the Spanish Ministry of Science and Innovation through a Research Contract from the "Juan de la Cierva Subprogram". The economical support of the European Social Fund and of the Aragon Government (DGA) through their program for financing research in Consolidated Groups is also acknowledged. The investigation has been also partially financed by the project CGL2010-16775 (Ministerio de Ciencia e Innovación and FEDER). The comments and suggestions of Dr. Dioni I. Cendón and an anonymous reviewer have greatly improved the quality of the manuscript and are gratefully acknowledged.

\section{REFERENCES}

Armstrong, A.K., 1972. Pennsylvanian carbonates, paleoecology, and rugose colonial corals, north flank, eastern Brooks Range, arctic Alaska. United States Geological Survey, 747 (Professional Paper), 21pp.

Buddington, A.F., Chapin, T., 1929. Geology and mineral deposits of southeastern Alaska. United States Geological Survey, 800 
(Bulletin), 398pp.

Colpron, M., Nelson, J.L. 2011. A Palaeozoic NW passage and the Tinamian, Caledonian and Uralian connections of some exotic terranes in the North American Cordillera. In: Spencer, A.M., Embry, A.F., Gautier, D.L., Stoupakova, A.V., Sorensen, K. (eds.). Arctic Petroleum Geology. London, Geological Society, 35 (Memoirs), 463-484.

Dutro, J.T.Jr., Douglass, R.C., 1961. Pennsylvanian rocks in southeastern Alaska. United States Geological Survey, 424-B (Professional Paper), B239-B241.

Dybowski, W.N., 1873. Monographie der Zoantharia Sclerodermata Rugosa aus der Silurformation Estlands, Nordlivlands und der Insel Gotland. Archiv für Naturkunde der Livlands, Estlands, Kurlands, 1, 257-414.

Fedorowski, J., Bamber, E.W., Stevens, C.H., 2007. Lower Permian colonial rugose corals, western and northwestern Pangaea: Taxonomy and Distribution. Ottawa (Ontario, Canada), National Research Council Press, 231pp.

Gardner, M.C., Bergman, S.C., Cushing, G.W., Mackevett, E.M.Jr., Plafker, G., Campbell, R.B., Dodds, C.J., Mcclelland, W.C., Muller, P.A., 1988. Pennsylvanian pluton stiching of Wrangellia and the Alexander terrane, Wrangell Mountains, Alaska. Geology, 16, 967-971.

Gorsky, I.I., 1938. Kamennougolnye koralloy Novoy Zemli (In Russian). Trudy Vsesoyuznogo Arkticheskogo Instituta, 93, $1-221$.

Hill, D., 1981. Supplement 1. Rugosa and Tabulata. In: Teichert, C. (ed.) Treatise on invertebrate paleontology. Part F. Coelenterata. Boulder (Colorado) and Lawrence (Kansas), Geological Society of America and University of Kansas Press, F1-F762.

Katvala, E.C., Henderson, C.M., 2002. Conodont sequence biostratigraphy and paleogeography of the PennsylvanianPermian Mount Mark and Fourth Lake Formations, southern Vancouver Island. In: Hills, L.V., Henderson, C.M., Bamber, W. (eds.). Carboniferous and Permian of the World. Canadian Society of Petroleum Geologists, 19 (Memoir), 461-478.

Katvala, E.C., Henderson, C.M., 2007. Updates to the Late Paleozoic history of the Alexander Terrane. Geological Society of America, Abstracts with Programs, 39(6), 490.

Katvala, E.C., Henderson, C.M., Beatty, T.W., 2009. Reworked conodonts of the Alexander Terrane: Utility and lithologic occurrence. 2009, Permophiles: Newsletter of the
Subcommission on Permian Stratigraphy, 53(1, Abstracts), 25.

Kawamura, T., Stevens, C.H., 2012. Middle Pennsylvanian rugose corals from the Baird Formation, Klamath Mountains, northwestern California. Journal of Paleontology, 86, 513520.

Lin, B.Y., Xu, S.Y., Jia, H.Z., Guo, S.Z., Ouyang, X., Wang, Z.J., Ding, Y.J., Cao, X.D., Yan, Y.Y., Chen, H.C., 1995. Monograph of Palaeozoic corals. Rugosa and Heterocorallia (In Chinese with English summary). Beijing, Geological Publishing House, I-VII+1-778.

Loney, R.A., 1964. Stratigaphy and petrography of the PybusGambier area, Admiralty Island, Alaska. United States Geological Survey, 1178 (Bulletin), 103pp.

Muffler, L.J.P., 1967. Stratigraphy of Keku Islets and neighboring parts of Kuiu and Kupreanof Islands, southeastern Alaska. United States Geological Survey, 1241-C (Bulletin), C1-C52.

Sando, W.J., 1985. Paraheritschioides, a new rugose coral genus from the Upper Pennsylvanian of Idaho. Journal of Paleontology, 59, 979-985.

Smith, S., 1935. Two Anthracolithic corals from British Columbia and related species from the Tethys. Journal of Paleontology, 9, 30-42.

Sorauf, E.J., 1970. Microstructure and formation of dissepiments in the skeleton of the recent Scleractinia (hexacorals). Akademie der Wissenschaften und der Literatur. Maintz. Biomineralization Forschungsberichte, 2, 1-22.

Spasskiy, N.Ya., Kachanov, E.I., 1971. Novye primitivnye rannekamennougolnye korally Altaya i Urala (In Russian). Zapiski Leningradskogo Gornogo Instituta, 59, 48-64.

Vassilyuk, N.P., Kosyreva, T.A., 1974. Noviy rod korallov Copia (Rugosa) iz Nizhnego Karbona Voronezhskoi Anteklizy (In Russian). Paleontologicheskiy Sbornik, 11, 31-34.

Verrill, A.E., 1865. Classification of polyps (Extract condensed from a synopsis of the polypi of the North Pacific Exploring Expedition, under captains Ringgold and Rodgers, U.S.N.). Proceedings of the Essex Institute, 4, 145-149.

Wells, J.W., 1969. The formation of dissepiments in zoantharian corals. In: Campbell, K.S.W. (ed.). Stratigraphy and Palaeontology: Essays in honour of Dorothy Hill. Canberra, Australian National University Press, 17-26.

Yabe, H., 1950. Permian corals resembling Waagenophyllum and Corwenia. Proceedings of the Japanese Academy, 26, 74-79.

Manuscript received June 2013;

revision accepted January 2014;

published Online February 2014. 


\section{APPENDIX I}

USGS 4305-PC. Petersburg 1:4 quadrangle, Kuiu Island, west of south end of Keku Island Group. Limestone interbedded with basaltic lava; limestone with many layers rich in corals identified as Lonsdaleia and Clisiophyllum by Buddington and Chapin (1929), both taxa needing revision. These fossils apparently are from the Volcanic Member of the Saginaw Bay Formation of Muffler (1967). Probably Moscovian in age. Collected by A.F. Buddington, 1922 (see Buddington and Chapin, 1929) from rocks called the "Lower Division of the Permian".

USGS 5134-PC. Islet in Keku Strait about $1 \frac{1 / 4}{4}$ mile eastnortheast of point 4 miles southeast of Point Cornwallis. Limestone interbedded with andesitic flows and tuff. The coral Londaleia was listed as present by Buddington and Chapin, 1929). Fossils reported by Dutro and Douglas (1961) include brachiopods, gastropods, pelecypods, bryozoans, and the corals Syringopora, Favosites, Striatopora, and Lonsdalia. All of these generic identifications require revision. Muffler's (1967) map suggests the Silty Limestone Member of the Saginaw Bay Formation, but Katvala (pers. comm.) has placed it in the Volcanic Member. Conodonts suggest a Moscovian in age. Collected by A.F. Buddington, 1922 (see Buddington and Chapin, 1929).

USGS loc. 21334-PC (63Amp 239, map locality 55 of Muffler (1967), NE shore of Kuiu Island (Cornwallis Peninsula), lat. $56^{\circ} 53.21^{\prime} \mathrm{N}$, long. $134^{\circ} 0.245^{\prime} \mathrm{W}$. Light gray limestone interbedded with pillow lava; Volcanic Member of Saginaw Bay Formation. Brachiopods were considered Atokan ( Bashkirian) in age by Dutro and Douglas (1961). However this collection is here considered Moscovian in age based on its occurrence in the Volcanic Member of the Saginaw Bay Formation. Collected by Muffler, 1965 (see Muffler, 1967).

SMI 2004, Samtron Monitor Island, Keku Strait Region. Small, unnamed island in northwest Keku Islets close to Cornwallis Peninsula on Kuiu Island located about 4.5 miles eastsoutheast of Cornwallis Point. From coastal outcrop on north and northwest side of island. Mapped as the Volcanic Member of the Saginaw Bay Formation by Muffler (1967). Lat. 56 55.399'N, long. $134^{\circ} 08.546^{\prime} \mathrm{W}$. Fossils collected from Muffler's localities $78,79,80$. Probably Moscovian in age. Collected by Erik Katvala, 2004.

SOB-F1, School of Bass, Saginaw Bay, northeastern Kuiu Island, small cove on east side of Saginaw Bay located about 4 miles southeast of Cornwallis Point along a mostly continuous section along southeast-facing shoreline. From an undescribed conglomerate at the top? of the Chert and Limestone Member, here included in the Silty Limestone Member of the Saginaw Bay Formation. Probably Moscovian in age. Collected by Erik Katvala, 2005.

FH-C-F2, Floating Hatchery, Keku Strait Region, south end of Cornwallis Peninsula on the northeast shore of Kuiu Island, mapped as Volcanic Member of the Saginaw Bay Formation by Muffler (1967). Section is northwest of a small, narrow inlet at the southern end of this unit as mapped by Muffler (1967). A floating hatchery is located in this inlet. Probably Moscovian in age. Collected by Erik Katvala (2005). 